\title{
Developments in in-situ (trans) esterification for biodiesel production: A critical review
}

\author{
Alchris Woo Go ${ }^{\text {a,b }}$, Sylviana Sutanto ${ }^{a}$, Lu Ki Ong ${ }^{a}$, Phuong Lan Tran-Nguyen ${ }^{\text {, }}$ \\ Suryadi Ismadji ${ }^{\mathrm{d}}$, Yi-Hsu Ju ${ }^{\mathrm{a}, *}$ \\ a Department of Chemical Engineering, National Taiwan University of Science and Technology, 43, Keelung Rd., Sec. 4, Taipei 106-07, Taiwan \\ ${ }^{\mathrm{b}}$ Department of Chemical Engineering, University of San Carlos - Talamban Campus, Gov. M. Cuenco Avenue, Nasipit, Talamban, Cebu City 6000, Philippines

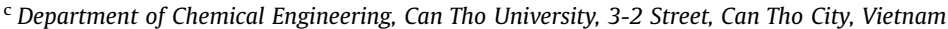 \\ d Department of Chemical Engineering, Widya Mandala Surabaya Catholic University, Kalijudan 37, Surabaya 60114, Indonesia
}

\section{A R T I C L E I N F O}

\section{Article history:}

Received 4 October 2014

Received in revised form

1 January 2016

Accepted 13 January 2016

\section{Keywords:}

Biodiesel

Challenges

Economic viability

Future prospects

In-situ (trans) esterification technologies

\begin{abstract}
A B S T R A C T
Biodiesel is a biofuel used as an alternative for petroleum diesel. The main obstacle in the widespread use of biodiesel lies mainly on its cost and current state of the technology to process a wide array of feedstock. The cost of biodiesel production is still high compared to that of petroleum based diesel fuel. The decrease of production cost can be achieved through the utilization of cheap, low quality feedstock and the development of simpler production process. In-situ (trans) esterification (ISTE) is an alternative route in synthesizing or producing biodiesel. ISTE involves lesser steps as it eliminates the need for lipid or oil extraction prior to (trans)esterification. A detailed comparison of the various strategies, mechanism involved and technologies developed since 1985 on ISTE processes is described in this review. This review tackles several technological gaps needing to be bridged and addressed in future studies. Furthermore, future prospects and possible developments in ISTE is also looked into.
\end{abstract}

(c) 2016 Elsevier Ltd. All rights reserved.

\section{Contents}

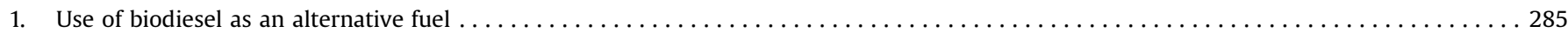

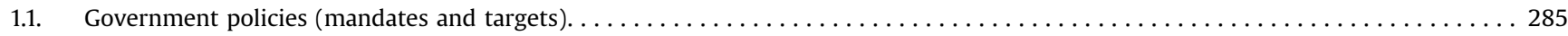

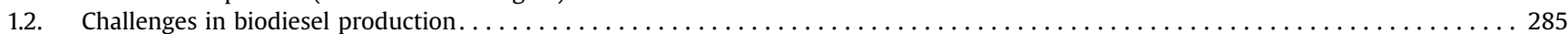

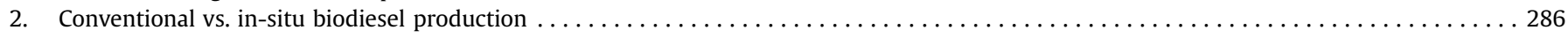

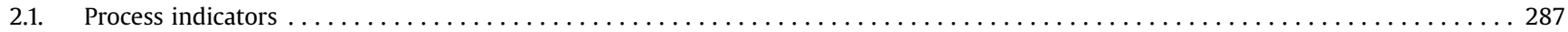

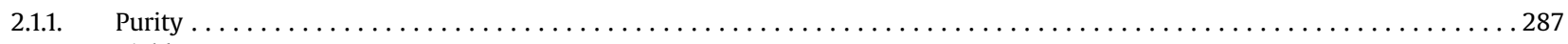

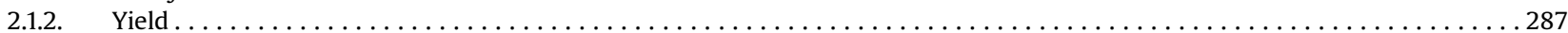

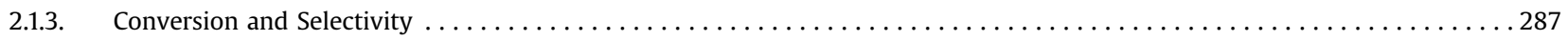

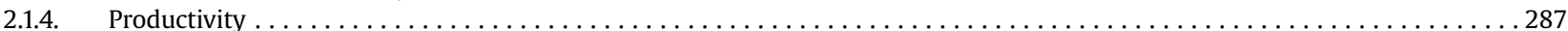

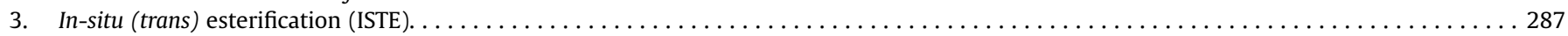

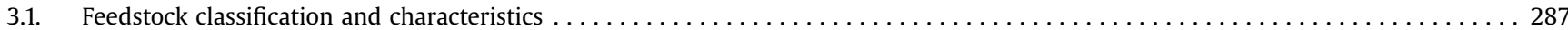

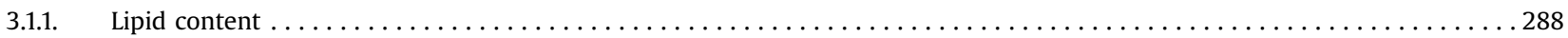

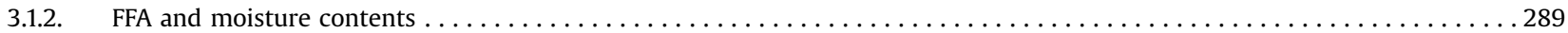

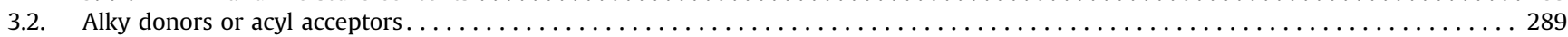

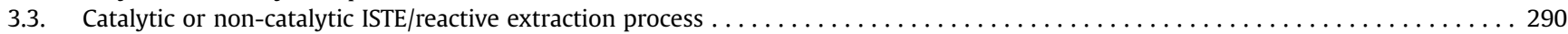

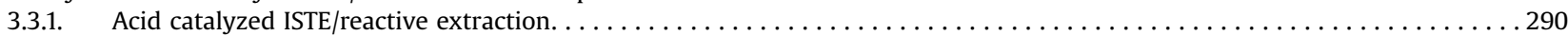

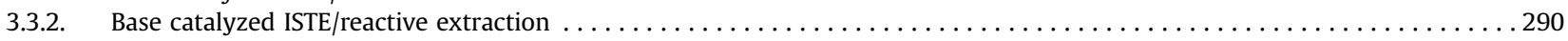

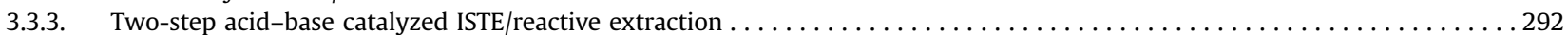

\footnotetext{
Abbreviations: ISTE, In situ (trans) esterification; FFA, Free fatty acids; MG, Monoacylglyceride; DG, Diacylglyceride; TG, Triacylglyceride; FAME, Fatty acid methyl ester;

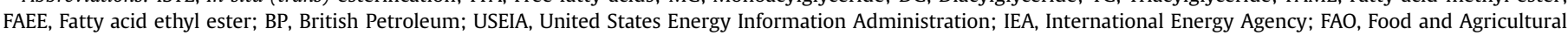
Organization of the United Nations

* Corresponding author. Tel.: +886227376612.

E-mail address: yhju@mail.ntust.edu.tw (Y.-H. Ju).
} 


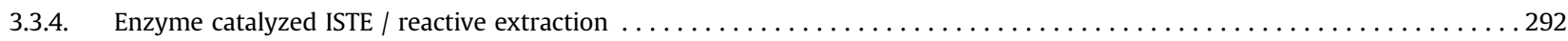

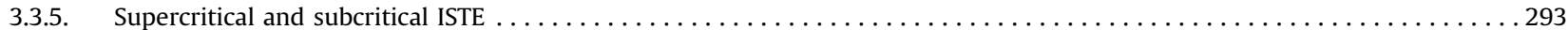

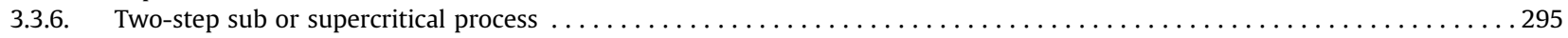

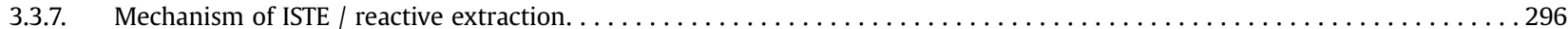

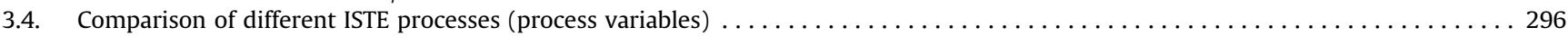

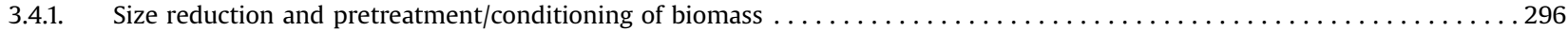

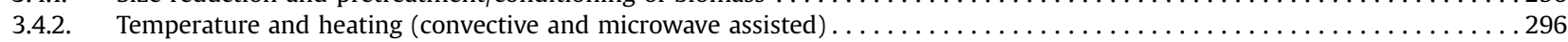

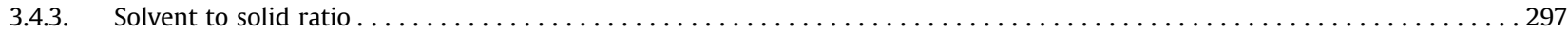

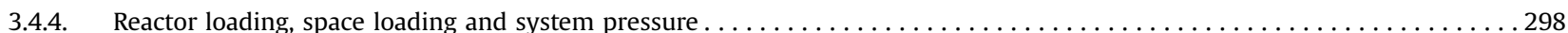

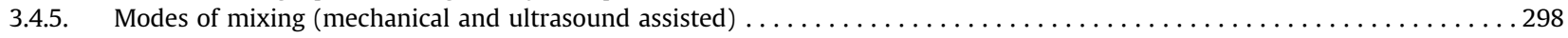

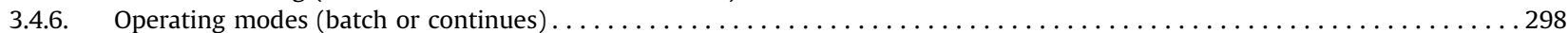

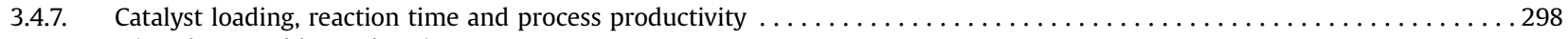

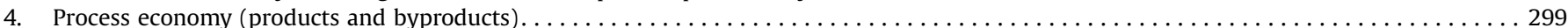

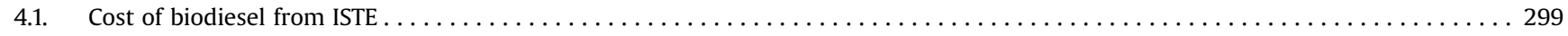

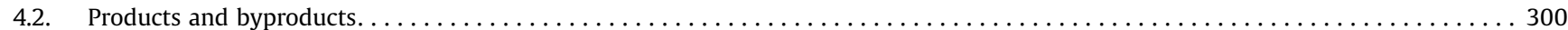

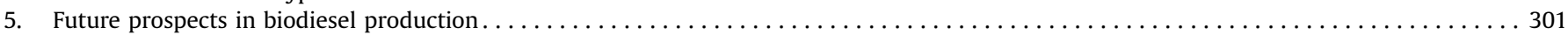

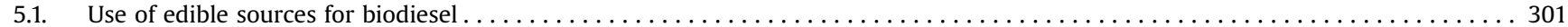

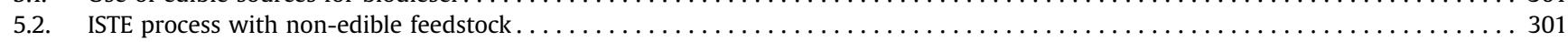

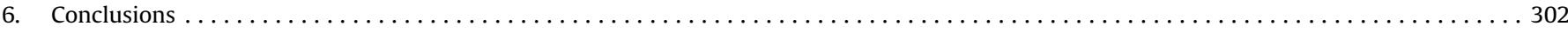

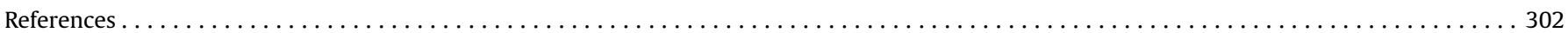

\section{Use of biodiesel as an alternative fuel}

The interest in using fuels derived from vegetable oil was triggered by several factors including: environmental concerns to reduce greenhouse gas emissions [1]; depleting crude oil reserves [2] and volatility of crude oil prices due to geopolitical tension in the Middle East [3]. Although, vegetable oil based fuels could generally be referred to as biodiesel, the term "biodiesel" is often used to refer to the ester products produced in the (trans)esterification of lipids.

(Trans)esterification process involves reacting acylglycerides and free fatty acid (FFA) with short chain alcohols. Earlier approaches to synthesize biodiesel only employed methanol/ ethanol as the source of alkyl group. Recent approaches involved the use of short chain esters or acetates (methyl/ethyl acetate) [46], alkyl carbonates (dimethyl/diethyl carbonate) [6-10], through both trans and (inter)esterification.

\subsection{Government policies (mandates and targets)}

According to United States Energy Information Administration (USEIA) [11], 10 gallons of diesel is produced for every 42 gallons of crude oil (approx. 24\%). Although diesel may be used in energy generation it is widely noted for its use as transportation fuel. As an estimation, a barrel of biodiesel is equivalent to 0.88 barrel of crude oil [12], implying that $\sim 14 \%$ more of the world diesel consumption should be produced if biodiesel were to entirely replace petro-diesel.

As of the moment, countries and different regions around the world mandate or aim to utilize biodiesel as fuel in transportation at a blend of $2-20 \%$ (B2 to B20) [13]. Table 1 compares the annual biodiesel production and the required biodiesel based on mandate of countries around the world.

Germany, Argentina, Brazil, France and Indonesia are among the top biodiesel producing countries. Only Philippines and Taiwan have produced enough biodiesel to realistically meet their country's mandate. A review published in 2006 reported the top ten countries to have the potential to produce biodiesel (Table 2) based on the commercially traded and exported processed plant oils and animal fats by each country [14]. Malaysia is far ahead of others based on its potential to produce biodiesel and has been misquoted by many to be listed as the top biodiesel producing country. Data gathered from USEIA showing the top ten producers of biodiesel based on their total annual production as of 2011 as summarized in Table 2, resulted to a different list as compared to the top ten potential countries. European countries lead by Germany top the world production of biodiesel, while only Indonesia among the top potential Asian countries has made it to the top five producing countries.

With the large gap between the biodiesel demand and the current production capacity, there is still room for improvement which requires intensive research in order to realistically meet the demands. USA is the top consumer followed by Germany and Spain. Interestingly, not all the top producers of biodiesel are the largest biodiesel consumers with some countries consuming more than their annual production.

\subsection{Challenges in biodiesel production}

With regards to feedstock for producing biodiesel, $28 \%$ of feedstock that the potential countries uses is soybean oil, $22 \%$ is palm oil, $20 \%$ is animal fats, $11 \%$ is coconut oil, while rapeseed, sunflower and olive oil each is $5 \%[2,15]$. These feedstock oils are mostly edible. The use of edible oil as biodiesel feedstock competes with human consumption for food. Moreover, using refined edible oils in biodiesel production has been estimated to account for $70 \%$ of the total production cost.

To address these concerns, researches have been looking into alternative feedstock specifically from non-edible plant and microbial sources and waste oils. Problems associated with these types of feedstock are the presence of significant amount of impurities like FFA, moisture, waxes and gums, which would require additional processing steps before these feedstock can be used for biodiesel production using the conventional basecatalyzed process. Otherwise, a process requiring the use of specific catalyst and/or solvent conditions may be needed to effectively utilize this feedstock.

In order to realize the widespread use of biodiesel, its production should not be based on a single feedstock. Utilization of a pool of potential feedstock might be necessary to meet the demands for biodiesel yet maintaining environmental balance. If this has to be adopted, a versatile and robust process should be developed, capable of processing a wide range of feedstock with a fixed processing condition, whereby allowing ease in operation and reduced pretreatment steps. Another important consideration is the reduction of cost through maximized utilization of the feedstock and co-production of biomass based products, which 
Table 1

Biodiesel mandates, feedstock and production capacity of different countries [11-15, 136].

\begin{tabular}{|c|c|c|c|c|c|c|}
\hline Regions/countries & Feedstock & $\begin{array}{l}\text { Annual biodiesel production } \\
\text { (Mt) }\end{array}$ & Blend (\%) ${ }^{\mathrm{b}}$ & Crude oil (Mt) & Diesel (Mt) ${ }^{d}$ & Required biodiesel (Mt) \\
\hline \multicolumn{7}{|l|}{ Americas } \\
\hline Argentina & Soybean & 2.4 & 10 & 28.2 & 6.7 & 0.7 \\
\hline Brazil & Soybean, Palm, Castor, Cottonseed & 2.4 & $5-6$ & 125.6 & 29.9 & 1.6 \\
\hline Canada & Rapeseed, Soybean & 0.1 & 2 & 104.3 & 24.8 & 0.5 \\
\hline Chile & - & 0 & $5-6$ & 17.9 & 4.3 & 0.2 \\
\hline Costa Rica & - & 0 & 20 & - & - & - \\
\hline Ecuador & - & 0 & $5-10$ & 11 & 2.6 & 0.1 \\
\hline Paraguay & - & $*$ & 1 & - & - & - \\
\hline Peru & - & * & 5 & 9.6 & 2.3 & 0.1 \\
\hline Uruguay & - & * & 2 & - & - & - \\
\hline USA & Soybean Peanut, Waste oil & 3.2 & $10-20$ & 819.9 & 195.2 & 21.7 \\
\hline $\begin{array}{l}\text { European Union } \\
\text { Asia Pacific }\end{array}$ & Rapeseed/ Sunflower & 9.1 & 7.5 & 611.3 & 145.5 & 12.2 \\
\hline Australia & - & 0.1 & 2 & 46.7 & 11.1 & 0.2 \\
\hline China & Jatropha, Rapeseed, Waste oil & 0.4 & 10 & 483.7 & 115.2 & 12.8 \\
\hline Fiji & - & * & 5 & - & - & - \\
\hline India & $\begin{array}{l}\text { Jatropha, Soybean, Rapeseed, Sunflower, } \\
\text { Peanut, Palm }\end{array}$ & 0.1 & 20 & 171.6 & 40.9 & 10.2 \\
\hline Indonesia & Palm, Jatropha, Coconut & 1.0 & $2-2.5$ & 71.6 & 17.0 & 0.3 \\
\hline Malaysia & Palm & 0.1 & 5 & 29.8 & 7.1 & 0.4 \\
\hline Philippines & Coconut, Jatropha & 0.1 & 2 & 13 & 3.1 & 0.1 \\
\hline South Korea & Waste oil & 0.3 & 2 & 108.8 & 25.9 & 0.5 \\
\hline Taiwan & Waste oil & 0.1 & 1 & 42.2 & 10.0 & 0.1 \\
\hline $\begin{array}{l}\text { Thailand } \\
\text { Africa }\end{array}$ & Palm, Jatropha, Coconut & 0.5 & 5 & 52.4 & 12.5 & 0.7 \\
\hline South Africa & - & $*$ & 5 & 26.9 & 6.4 & 0.3 \\
\hline Total & & 19.9 & & & & 62.8 \\
\hline
\end{tabular}

a 2011 data obtained from United States Energy Information Administration (U.S.E.I.A.) [11]

${ }^{b}$ Percent (\%) biodiesel blended in petroleum diesel [13].

c Crude oil consumption at the end of 2012 [12].

d 10 barrels of diesel produced per 42 barrels of crude oil [11].

e 1 ton of biodiesel $=0.88$ ton of crude oil/diesel [12].

Table 2

Top ten countries in terms of potential, production and consumption of biodiesel in million liters per annum [11,12,14].

\begin{tabular}{|c|c|c|c|c|c|c|}
\hline Rank & Potential countries & Capacity (ML) & Producing countries & Produced (demand) ${ }^{a}$ & Consuming countries & Consumed (ML) \\
\hline 1 & Malaysia & 14540 & Germany & 3097 (2507) & USA & 3356 \\
\hline 2 & Indonesia & 7595 & Argentina & $3018(816)$ & Germany & 2750 \\
\hline 3 & Argentina & 5255 & Brazil & $2747(1864)$ & Brazil & 2611 \\
\hline 4 & USA & 3212 & France & 2673 (1819) & France & 2350 \\
\hline 5 & Brazil & 2567 & Indonesia & $1973(350)$ & Spain & 1857 \\
\hline 6 & Netherlands & 2496 & Spain & $1161(1435)$ & Italy & 1798 \\
\hline 7 & Germany & 2024 & Italy & $696(1443)$ & UK & 928 \\
\hline 8 & Philippines & 1234 & Thailand & $650(815)$ & Poland & 870 \\
\hline 9 & Belgium & 1213 & Netherlands & $592(992)$ & Argentina & 850 \\
\hline 10 & Spain & 1073 & Colombia & $557(-)$ & Thailand & 591 \\
\hline
\end{tabular}

${ }^{\text {a }}$ Demand is estimated based on the petro-diesel consumption and reported biodiesel policy.

could either be "high value-low volume" or "low value-high volume" products.

In view of the many challenges involved, a possible workaround in the production of biodiesel is the improvement of the biodiesel production process through in-situ (trans) esterifictaion. This review focuses on the advancements of the process and potential gaps needed to be filled in order to realistically employ it at industrial scales. It is the objective of this review to look into the parameters, measures and responses affecting the said process. This review also tackles the mechanism involved in in-situ transesterification, its potentials, economic viability and future prospects of the process.

\section{Conventional vs. in-situ biodiesel production}

Various processes have been developed for the production of biodiesel. These processes could be classified according to the catalyst used, state of the solvent involved or even according to steps or stages implemented during the (trans)esterification process. In a broader perspective, (trans)esterification processes can generally be classified into the conventional and in-situ processes. As can be seen in Fig. 1, conventional (trans)esterification processes involve the extraction of oils or lipids from biomass, which then is further processed to produce biodiesel. On the other hand, in-situ process in the context of transesterification refers to the direct use of the lipid-rich biomass without prior extraction of the lipids and allowing the (trans)esterification reaction to take place within the solid matrix [16-18]. However, reaction usually takes place while extraction of the lipids and/or the products simultaneously occurs, which may technically be referred to as reactive extraction $[19,20]$. In certain cases, extraction and (trans)esterification reaction may actually occur sequentially and is still referred to by several studies as direct or in-situ (trans) 


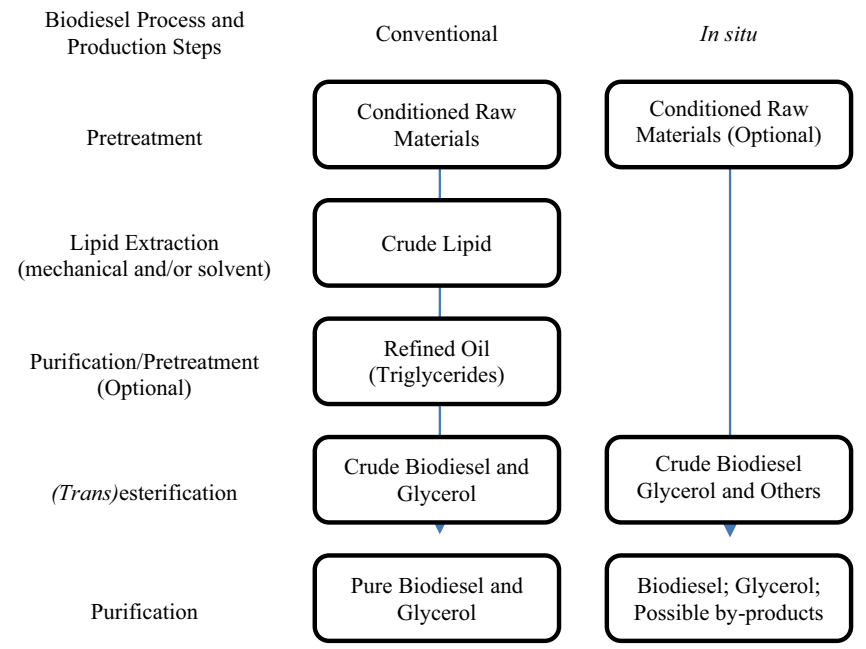

Fig. 1. A comparison of major processing steps between conventional and in situ (trans) esterification (ISTE).

esterification [21-23]. Nevertheless, through these processes, biodiesel could be produced with fewer overall production steps. A detailed discussion of the mechanism to define ISTE will be discussed in detail in the later Section (3.3.7)

An obvious difference in the major production steps is the need to extract and the possible need to refine the lipid material from solid feedstock in separate processing steps. Mechanical press and solvent extractor used in the extraction process and refining of oils are usually costly. Eliminating the oil extraction steps not only reduces the production steps but may also result in a lower initial investment cost and reduced overhead cost. The quality of biodiesel produced from ISTE has been tested by Hass and Scott [24] and compared to ASTM D6751 standards, while Kasim et al. [3] later also compared these results to EN 14214 standards, with the FAME produced passing all the standard tests. In certain cases it requires additional washing to eliminate or lower down the FFA content. To have a better understanding of the potentials and drawbacks of ISTE process, a thorough review of the developments in the past 30 years on ISTE will be discussed in the subsequent sections.

\subsection{Process indicators}

Process indicators are numerical measures to express the efficiency of a process which are purity, yield and conversion.

\subsubsection{Purity}

Purity of the biodiesel is commonly measured and calculated from results of chromatographic analysis of biodiesel product. Results are often expressed as percentage of methyl or ethyl esters in the product.

\subsubsection{Yield}

Process yield $\left(Y_{P}\right)$ is a measure of a plant, reactor or process performance, defined as the amount of product (biodiesel) produced relative to the amount of theoretical maximum (stoichiometric) [25] product possibly produced from the feedstock or raw material utilized in a process (Eq. (1)). Several different definitions for yield are available [25].

Conventional biodiesel production yield $\left(Y_{L}\right)$ may simply be the total amount of biodiesel produced per amount of oil/lipid processed during the reaction (Eq. (2)). This definition is adopted since the lipid material involved is usually a mixture of various compounds contributing to produce biodiesel. The same may be adopted in ISTE to have a comparison with the conventional process, but requires the prior knowledge of how much oil is contained in the biomass being used in ISTE. Since solid biomass is directly used in ISTE, yield $\left(Y_{S}\right)$ is better expressed as the amount of biodiesel produced relative to the amount of oil-bearing biomass processed (Eq. (3)).

Yield, $\quad \mathbf{Y}_{\mathbf{P}}=\frac{\mathbf{M}_{\text {crude product }} \times \text { Purity }}{\mathbf{M}_{\text {theoretical maximum product }}}$

Yield, $\quad \mathbf{Y}_{\mathbf{L}}=\frac{\mathbf{M}_{\text {crude product }} \times \text { Purity }}{\mathbf{M}_{\text {lipid material }}}$

$$
\begin{aligned}
\text { Yield, } Y_{S}= & \frac{M_{\text {product }(\text { FAME })}}{M_{\text {solid biomass }}}=\frac{M_{\text {crude product }} \times \text { Purity }}{M_{\text {lipid material }}} \\
& \times \frac{M_{\text {lipid material }}}{M_{\text {solid biomass }}}
\end{aligned}
$$

Yield in terms of available lipid material $\left(Y_{L}\right)$ and in terms of the solid biomass $\left(Y_{S}\right)$ processed can be related through the amount of lipid material present or contained in the biomass.

\subsubsection{Conversion and Selectivity}

Conversion is defined as the fraction of a specified reactant that reacted (Eq. (4)), while selectivity is a measure of how efficient the reactant is converted to the desired product, which is related through the reactions stoichiometry (Eq. (5)). Multiplying conversion and selectivity gives process yield $\left(Y_{p}\right)$.

$$
\begin{aligned}
& \text { Conversion, } X=\frac{M_{\text {lipid material reacted }}}{M_{\text {initial lipid material }}} \\
& \text { Selectivity, } S=\frac{M_{\text {product }(F A M E)}}{M_{\text {lipid material reacted }} \times F_{\text {stoichiometric factor }}}
\end{aligned}
$$

\subsubsection{Productivity}

An important indicator but often not taken into consideration is the process productivity. For a generalized definition, Eq. (6) may be adopted.

Productivity, $P=\frac{\text { Yield }}{\text { Reactor Volume } \times \text { Time }}$

\section{In-situ (trans) esterification (ISTE)}

Harrington and D'Arcy-Evans works [16,18] are among the earliest to study ISTE process or direct transesterification of oils in sunflower seeds in 1985 . But technically speaking, this approach may be dated back to 1966 when Dugan [17] carried out direct acid catalyzed methylation of lipids in biological materials. The next publication involving this process appeared in 1998 and gained much interest from researchers after another decade starting in 2006-2007 using oil bearing seeds, agricultural biomass and microbial biomass. A possible reason behind the renewed interest in ISTE is due to the economics of conventional biodiesel production. In 2006, Haas and co-workers revealed in an economic analysis that the use of refined lipid as biodiesel feedstock occupies almost $70 \%$ of total operating cost in biodiesel production [26]. Significant increase of effective biodiesel production research may also be due to political influences resulting from government funding and mandates [27]. Fig. 2 shows a histogram on the researches and publications on ISTE between 1985 and 2015.

\subsection{Feedstock classification and characteristics}

Over 350 oil bearing materials have been explored for potential feedstock for biodiesel production [15]. They can be classified into 


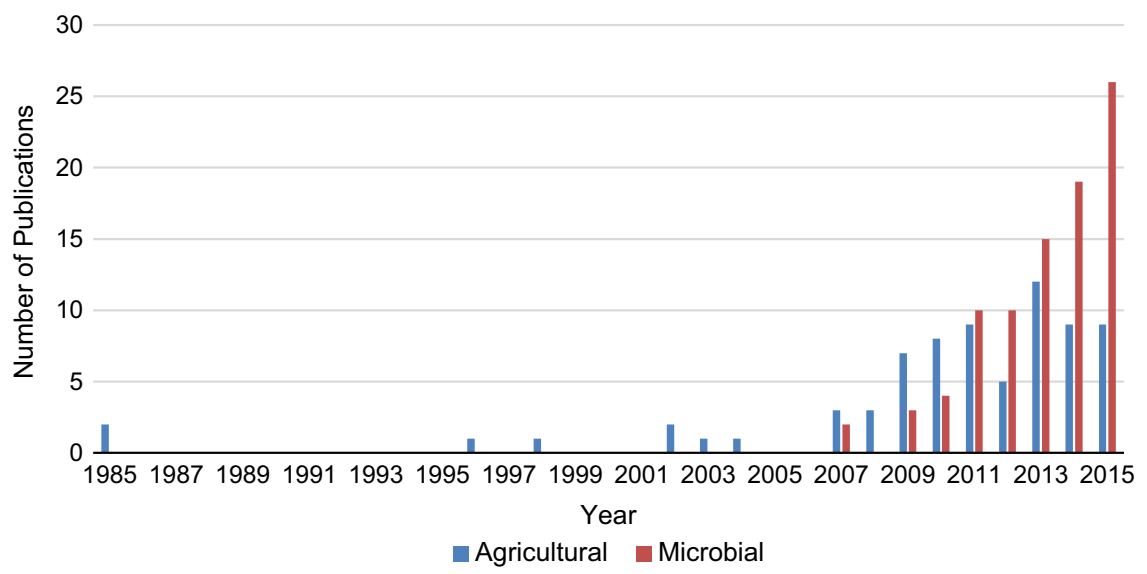

Fig. 2. Researches and publications on ISTE from 1985 to 2015 (Data gathered from Scopus and Google Scholar Database).

oil seeds, agricultural residues and microbial biomass. A pool of potential feedstock is necessary in order to cater the demand in biodiesel, since most of these feedstock are often bound to seasonal, climatic and geographical limitations. Interestingly, among the hundreds of feedstock explored, only a fraction has been investigated for possible use in ISTE. Table 3 is a summary of common feedstock reported in literature, which have been utilized in ISTE process.

The common characteristics of the feedstock that most researches looked into for biodiesel production includes: lipid content, FFA content, moisture content and productivity or availability of the feedstock. As can be seen in Table 3, several of the characteristics of a given feedstock are usually not reported, which could greatly influence the assessment of the potential of using such feedstock. Each of these characteristics will be discussed in the following sections. Data of the annual production and yield of agricultural oil seeds of all countries can be found in the database of the Statistical Division of the Food and Agricultural Organization of the United Nations (FAOSTAT). But listed in the data banks are mostly edible agricultural sources. Potential non-edible feedstock is not taken into account probably due to their lower trade quantities in the global market. For potential non-edible feedstock, yields and productivity are often reported in journals referring to experimental results and estimations which are prone to high variability and errors. Productivity of several agricultural feedstock and oleaginous microbial species can be seen elsewhere [28].

\subsubsection{Lipid content}

The maximum extractable lipid of a biomass is usually determined by solvent extraction. Oil seeds normally comprise two distinct parts: the kernel where most lipids/oils are stored and the shell which contains very little lipid $(<2 \%$ ). Lipid contents may vary due to the differences in soil and nutrient conditions during cultivation and/or the handling of the seeds during lipid extraction.

Of the agricultural feedstock explored for ISTE, lipid contents below $20 \%$ can be associated with agricultural residues like bran, distiller grains and spent coffee grounds. Lipid content in oil seed is typically over $25 \%$ and can be as high as $50 \%$ for edible oil seeds and up to $70 \%$ for non-edible oil seeds. Lipid content is one of the important criteria for feedstock selection, but its availability and productivity plays an important role as part of the feedstock selection.

The variation of lipid content in microbial biomass and its profile are often explained as the consequence of differences in culturing. The only rule of thumb agreed in this field is that, the term oleaginous microbial biomass refers to the lipid content in dry biomass in excess of $20 \%$. Among microorganisms, bacteria have the fastest growth rate, yet are unsuitable for biodiesel
Table 3

Feedstock utilized in ISTE research $[18,20,24,42,53-56,58,59,63-67,74,79-$ 82,89,90,93,95-97,111-114,116-118,129-131,137-151].

\begin{tabular}{|c|c|c|c|}
\hline Feedstock & $\begin{array}{l}\text { Lipid con- } \\
\text { tent, \% }\end{array}$ & $\begin{array}{l}\text { Water/moisture } \\
\text { content, \% }\end{array}$ & $\begin{array}{l}\text { Free fatty acid } \\
\text { content, } \%\end{array}$ \\
\hline \multicolumn{4}{|l|}{$\begin{array}{l}\text { Agricultural biomass and } \\
\text { residues }\end{array}$} \\
\hline Sunflower seed & $37.8-55.6$ & $4.6-6.2$ & - \\
\hline Soybean & $22.6-25.8$ & $7.4-10.3$ & - \\
\hline Cottonseed & 34.6 & $\sim 2.0$ & $0.6-1.7$ \\
\hline Rapeseed/Canola & $40.4-48$ & $6-6.7$ & - \\
\hline Castor seed & $\sim 66$ & - & 0.4 \\
\hline Coconut meat & 55.2 & - & 6.9 \\
\hline $\begin{array}{l}\text { Physic nut (Jatropha curcas } \\
\text { L.) }\end{array}$ & $33.4-68.5$ & $\sim 4-5 \%$ & $0.7-14$ \\
\hline Grape seed & 18.4 & - & - \\
\hline $\begin{array}{l}\text { Karting (Calophyllum } \\
\text { innophyllum) }\end{array}$ & $60-75$ & - & - \\
\hline Capparis deciduas & 63.8 & - & - \\
\hline Balanites aegyptiaca & 46.7 & - & - \\
\hline Rice bran & $13.5-19$ & $4-12$ & $3.3-85$ \\
\hline Palm fiber & 49 & - & 1.8 \\
\hline Coconut waste & 24 & - & \\
\hline Distiller dried grains & 8.8 & 8.7 & - \\
\hline Spent Coffee grounds & $14-20$ & - & - \\
\hline \multicolumn{4}{|l|}{ Microbial biomass } \\
\hline \multicolumn{4}{|l|}{ Yeast and fungi } \\
\hline Yarrowia lipolytica & 58.5 & - & 78.98 \\
\hline Lipomyces starkeyi & 50.2 & - & - \\
\hline Rhodotorula glutinis & 32 & - & - \\
\hline Rhodosporidium toruloides & $58-59$ & _- & - \\
\hline Mortierella isabellina & 53.2 & - & - \\
\hline Mucor circinelloides & 22.9 & - & 3.6 \\
\hline \multicolumn{4}{|l|}{ Microalgae } \\
\hline Chlorella sp. & $12.8-82.8$ & $46-90$ & $3.2-6.01$ \\
\hline Nannochloropsis sp. & $12.5-52$ & $4.4-80$ & - \\
\hline Spirulina platensis & 10.95 & - & 2.04 \\
\hline Scenedesmus abundans & 30.5 & - & - \\
\hline \multicolumn{4}{|l|}{ Biological refuse } \\
\hline \multicolumn{4}{|l|}{ Sludge } \\
\hline Primary sludge & $\sim 14$ & - & - \\
\hline Secondary sludge & $3-40$ & $\sim 80-90$ & $20-50$ \\
\hline Meat and bone meal & 9.1 & 2.0 & - \\
\hline
\end{tabular}

*There could be more feedstock(s), the list is not comprehensive.

synthesis due to difficulty in extracting its extracellular polyhydroxyalkanoates which is the most abundant neutral lipid produced [29]. Thus, microorganisms like microalgae and yeast are widely studied due to its high lipid content (up to $50 \mathrm{wt} \%$ ). Recently, fungi like Aspergillus candidus [30] have also been explored. 


\subsubsection{FFA and moisture contents}

FFA and moisture contents are two important characteristics of both lipid and biomass. In conventional base-catalyzed biodiesel production, FFA and moisture content below 0.5 and $0.05 \%$, respectively $[31,32]$ are required to avoid saponification. Acidcatalyzed (trans)esterification can tolerate higher FFA and moisture contents (0.5\%) [33] but has its own limitations [34]. For enzymatic processes, the presence of water influences the reaction equilibrium and enzyme activity but its amount is highly dependent on feedstock and nature of the enzyme used [34]. In noncatalytic process under subcritical or supercritical solvent conditions, FFA (up to 30\%) and water (up to 50\%) present in the system may contribute as catalyst as reported in certain studies [35-38]. Generally, a process with higher tolerance to water is preferable as it tends to also have higher tolerance to FFA.

FFA content in ISTE process can be viewed in the same context with conventional processes, except for the fact that storage time of the biomass affects the FFA levels of the extractable lipid. As can be seen in Fig. 3, FFA levels in biomass increased significantly with increasing storage time, especially for microbial biomass (1-4 days) even when stored at $4{ }^{\circ} \mathrm{C}$ [39].

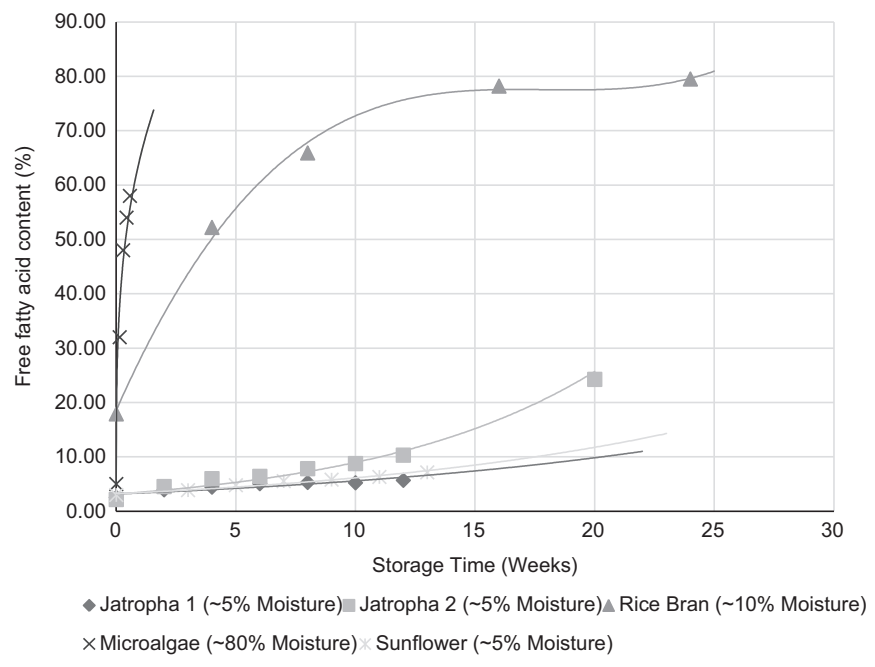

Fig. 3. Effect of storage time on FFA in the feedstock with different moisture contents $[39,42]$
Compared to agricultural biomass, microbial biomass has higher FFA content ( $>2 \%$ ). Biosynthesis of lipid always starts with the synthesis of fatty acids that are then joined to a glycerol phosphate backbone before being accumulated in the cell [40,41]. During the forced oil accumulation, inhibition of protein production occurs and disturbs this pathway therefore leaving more unreacted FFA in the cell. The other possibility is hydrolysis of the produced triacylglycerol (TG) by catalysis reaction of intracellular lipase [41].

Lipid constituents (AG, PL, WE) in the biomass are degraded to FFA through hydrolysis due to the presence of lipases, peroxidases and phospholipases in biomass $[39,42,43]$. Formation of FFA may be avoided if biomass is stored below $0{ }^{\circ} \mathrm{C}[39,43]$ or if biomass is stabilized through drying or heating to remove moisture and deactivate the enzymes [43]. Employing these treatments would be difficult if not impossible. This is due to the dispersed nature of the biomass and the difficulty to continuously gather freshly harvested biomass and these treatments require high energy inputs which affects overall production cost.

Agricultural biomass contains moisture not exceeding 10\%, while microbial sources contain as much as $90 \%$ (Table 1 ) and can be reduced to $70-80 \%$ after dewatering $[39,44,45]$. As mentioned earlier, the presence of water influences the FFA content during storage but its total removal would be difficult and impractical. A detailed review of recent advances (2010-2014) in utilizing wet algal biomass during extraction and (trans)esterification has been done by Park et. al. [46]. Nevertheless, with these considerations at hand, it is thus important that a robust process should be developed to cater the wide variability of a feedstock and/or the range of potential feedstock available.

\subsection{Alky donors or acyl acceptors}

Another reactant involved in biodiesel production is the alkyl donor or acyl acceptor, which at the same time acts as solvent in the reaction. A list of alkyl donors and their properties are summarized in Table 4.

The most widely used alkyl donors are alcohols, specifically methanol. Recent developments have successfully used crude biomethanol from wood gasification making biodiesel fully renewable [47]. Apart from bio-methanol, another alternative is the use of ethanol. Ethanol is preferred to certain extent due to its better solubility with oils and its lower toxicity compared to methanol.

Table 4

Properties of alkyl donating solvents utilized in ISTE.

\begin{tabular}{|c|c|c|c|c|c|c|}
\hline Alkyl donors & Methanol & Ethanol & Methyl acetate & Ethyl acetate & Dimethyl carbonate & Diethyl carbonate \\
\hline MW (g/mol) & 32.04 & 64.07 & 74.08 & 88.11 & 90.08 & 118.13 \\
\hline Density (g/ml) @ $25^{\circ} \mathrm{C}$ & 0.792 & 0.789 & 0.932 & 0.897 & 1.067 & 0.975 \\
\hline$T_{b}\left({ }^{\circ} \mathrm{C}\right)$ & 64.7 & 78.4 & 56.9 & 77.1 & 90.4 & 127 \\
\hline$T_{c}\left({ }^{\circ} \mathrm{C}\right)$ & 239.4 & 240.8 & 233.7 & 260.1 & 283.9 & - \\
\hline$P_{c}(\mathrm{MPa})$ & 8.1 & 6.1 & 4.6 & 3.9 & 4.8 & - \\
\hline$V_{c}(\mathrm{ml} / \mathrm{mol})$ & 118 & 167 & 229 & 294 & 257 & - \\
\hline$H_{\text {vap }}(\mathrm{kJ} / \mathrm{mol}) @ 25{ }^{\circ} \mathrm{C}$ & 35.28 & 38.56 & 32.5 & 31.94 & 33.0 & 40.2 \\
\hline Flash Point $\left({ }^{\circ} \mathrm{C}\right)$ & $11-12$ & $13-14$ & -13 & -4 & 16 & 25 \\
\hline Viscosity (mPa s) @ $25{ }^{\circ} \mathrm{C}$ & 0.593 & 1.144 & 0.385 & 0.455 & 0.423 & 0.749 \\
\hline $\log P @ 25{ }^{\circ} \mathrm{C}$ & -0.69 & -0.18 & 0.18 & 0.28 & 0.54 & 1.21 \\
\hline Dielectric constant @ $20{ }^{\circ} \mathrm{C}$ & 32.66 & 24.3 & 6.6 & 6.02 & 3.09 & 3.10 \\
\hline$L D_{50}(\mathrm{~g} / \mathrm{kg})$, oral, rat & 5.63 & 7.06 & 6.48 & 11.3 & $\sim 6.0$ & 15.0 \\
\hline \multicolumn{7}{|c|}{ Possible products during reaction } \\
\hline Reaction & \multicolumn{2}{|l|}{ Esterification } & \multicolumn{3}{|c|}{ Transesterification } & \\
\hline Fatty Acids & FAME, $\mathrm{H}_{2} \mathrm{O}$ & FAEE, $\mathrm{H}_{2} \mathrm{O}$ & $\begin{array}{l}\text { FAME, Acetic } \\
\text { Acid }\end{array}$ & $\begin{array}{l}\text { FAEE, Acetic } \\
\text { Acid }\end{array}$ & FAME, Carbonic Acid & FAEE, Carbonic Acid \\
\hline Reaction & \multicolumn{2}{|c|}{ Transesterification } & \multicolumn{2}{|c|}{ Interesterification } & & \\
\hline Acylglycerides & FAME, Glycerol & FAEE, Glycerol & FAME, Triacetin & FAEE, Triacetin & $\begin{array}{l}\text { FAME, Glycerol Carbonate, } \\
\text { Citramalic Acid }\end{array}$ & $\begin{array}{l}\text { FAEE, Glycerol Carbonate, Citra- } \\
\text { malic Acid }\end{array}$ \\
\hline
\end{tabular}


The exploration of alternative acyl acceptors are due to various reasons including: solubility between reactants [6], renewability of solvent of acyl acceptor [48], toxicity towards the catalyst [6], reaction reversibility [8], environmental and health concerns $[7,48]$, but more importantly to result in a glycerol free process, and to improve the quality of fuel produced and overall economics of the process $[49,50]$.

The use of alcohols in transesterification produces glycerol as a by-product, but due to the increasing scales of biodiesel production, the value of glycerol in the world market has significantly declined [49,51]. Employing other alkyl donors like short chain acetates and alkyl carbonates resulted in more valuable byproducts including triacetin (TA), glycerol carbonate (GC) and citramalic acid [7,9,49-51]. Non-alcohol alkyl donors provide certain advantages but are derived from their parent alkyl alcohols, which may entail higher cost. However, despite the low solubility, alcohols have higher reactivity as alkyl donor due to its simpler and smaller molecular structure.

\subsection{Catalytic or non-catalytic ISTE/reactive extraction process}

ISTE process may be further classified into catalytic and noncatalytic or according to the state of the solvent or reaction system into sub and supercritical. In the following sections, selected literatures will be discussed to provide better insights into the different ISTE processes.

\subsubsection{Acid catalyzed ISTE/reactive extraction}

Acid catalyst is favorably used for feedstock with high FFA and moisture contents (Table 5), to prevent soap formation. Sulfuric acid is commonly used using methanol or ethanol acting as alkyl donors $[16,18]$. Harrington and D'Arcy-Evans [18] reported that ISTE is a more efficient process than conventional methods due to the higher FAME yields. This was due to the fact that lipid components of the seed that were not extractable in conventional solvent extraction were converted into FAME. Both extracted kernel meals and seed hulls of sunflower still yielded certain amounts of FAME when utilized in ISTE [18]. Shells of sunflower comprise about $60 \%$ of the seeds dry weight [52], its extractable lipid is $<2 \%$ and might yield to only as much as 5\% of FAME when utilized in ISTE [18], thus making it not practically favorable in terms of process productivity. A separate study using ground sunflower kernels alone [53] resulted in higher FAME yields, since the starting material tend to have higher lipid content due to the removal of hulls or shells.
Non-edible feedstock like rice bran with its high FFA content have also been explored and is one of the most extensively studied feedstock due to its abundance and low cost. Ozgul-Yucel [54,55], initiated the study on using low quality rice bran (FFA content 74$85 \%)$. As shown in Fig. 3, bran stored over 2 months resulted in an FFA content of over $60 \%$ in the bran oil. Yustianingsih et al. [56] explored the use of rice bran with low $(<20 \%)$ and medium ( $<50 \%$ ) FFA content and obtained 89-96\% FAME yield using the same process conditions for both bran qualities, making it favorable for industrial application.

Table 6 is a summary of some microbial biomass studied in ISTE. Unfortunately, most studies used dry biomass and if wet biomass was utilized, its FFA content was not reported. Although high yields could still be obtained using wet biomass, much longer reaction times were required.

Compared to the conventional process, the amount of solvent, alkyl donor and sulfuric acid needed in ISTE is on average higher [57]. This is due to the high water content of biomass in ISTE process, which reduces acid concentration in the reaction and hinders solvent to lipid interaction. Other parameters, such as temperature, pressure, and reaction time are comparable to the conventional process.

Greener alternatives that have been proposed to substitute sulfuric acid are solid Lewis acids. The use of solid acid catalysts comes at the cost of lower reaction rate and higher reaction temperature and time. For ISTE, homogeneous acid is still favorable, as heterogeneous catalyst complicates the separation of residual solid biomass and reuse of the catalyst.

\subsubsection{Base catalyzed ISTE/reactive extraction}

In contrast to conventional process, the use of base catalyst in ISTE was explored much later than acid catalyst. In 2004, Haas [58] initiated the use of base catalyst and found that moisture content of 2-9\% in soybean distiller grain [24] and bone meals [59] can be tolerated due to the excess methanol used in ISTE thus, diluting the water present in the system.

Compared to agricultural biomass, the main obstacle for microbial biomass in using base as catalyst is its high FFA content. Velasques-Orta [60] used base as catalyst for the ISTE of microalgae containing $3.4 \%$ FFA but still obtained $>95 \%$ yield. Base catalyst is in principle not capable of converting FFA to FAME. The high amounts of alcohols used in ISTE results in suppressing saponification reaction. Base catalyst has been applied to a wide range of feedstock and alcohols as shown in Tables 7 and 8 .

Table 5

Acid catalyzed ISTE of agricultural biomass.

\begin{tabular}{|c|c|c|c|c|c|c|c|}
\hline Feedstock $\boldsymbol{k}^{\mathrm{a}}$ & Alkyl donor and co-solvent & $\begin{array}{l}S S R^{\mathrm{b}}(\mathrm{ml}: \\
\mathrm{g})\end{array}$ & Catalyst $^{\mathrm{c}}$ & $\begin{array}{l}\mathrm{T}\left({ }^{\circ} \mathrm{C}\right) / \boldsymbol{P} \\
(\mathrm{MPa})\end{array}$ & $t(h)$ & $\% Y_{s}\left(\% Y_{P}\right)$ & Ref. \\
\hline Sunflower seed O: 37.8 F: n.s. M: 6.2 & $\begin{array}{l}\text { Methanol } \\
\text { Ethanol }\end{array}$ & 10 & $\mathrm{H}_{2} \mathrm{SO}_{4}{ }^{\mathrm{c}}(3 \%)$ & $\begin{array}{l}64.5 / 0.1 \\
78.4 / 0.1\end{array}$ & 4 & $\begin{array}{l}40.9(102.6) \\
43.73 \\
(102.6)\end{array}$ & {$[16,18]$} \\
\hline Sunflower kernels O: 55.6 F: n.s. M: 5.5 & Methanol & 6.4 & $\mathrm{H}_{2} \mathrm{SO}_{4}(4.75 \%)$ & $\begin{array}{l}64.5 / 0.1 \\
30 / 0.1\end{array}$ & $\begin{array}{l}1 \\
4\end{array}$ & $\begin{array}{l}54.4(99.7) \\
54.2(99.3)\end{array}$ & [53] \\
\hline $\begin{array}{l}\text { Rice Bran O: } 16.9-18 \mathrm{~F}: 13.3-47.9 \mathrm{M}: 4.0 \mathrm{Mechanically} \\
\text { Stirred or Ultrasound assisted }(35 \mathrm{kHz} ; 500 \mathrm{~W})\end{array}$ & Methanol & 10 & $\mathrm{H}_{2} \mathrm{SO}_{4}(1.5 \%)$ & $60 / 0.1$ & 4 & $(89.2-96.3)$ & [56] \\
\hline Jatropha curcas L. O: 54.4 F: n.s. M: 5.4 & $\begin{array}{l}\text { Methanol }(7.5 \mathrm{ml} / \mathrm{g} \text { biomass }) \\
\text { Hexane }(0.75 \mathrm{ml} / \mathrm{g} \text { biomass })\end{array}$ & 8.25 & $\mathrm{H}_{2} \mathrm{SO}_{4}(1.1 \%)$ & $60 / 0.1$ & 24 & 54 & [148] \\
\hline Jatropha curcas L. O: 54.4 F: n.s. M: 5.4 & Methanol & 10.5 & $\mathrm{H}_{2} \mathrm{SO}_{4}(2.1 \%)$ & $60 / 0.1$ & 10 & 53 & [149] \\
\hline Coconut meat (Copra) O: 55.5 F: 6.9 M: 5.7 & $\begin{array}{l}\text { Methanol ( } 2 \mathrm{ml} / \mathrm{g} \text { biomass }) \mathrm{THF} \\
(0.8 \mathrm{ml} / \mathrm{g} \text { biomass })\end{array}$ & 2.8 & $\mathrm{H}_{2} \mathrm{SO}_{4}(12.5 \%)$ & $60 / 0.1$ & 20 & $53.4(96.7)$ & [145] \\
\hline
\end{tabular}

n.s.: not specified.

${ }^{a} \mathrm{O}$ : oil content , F: free fatty acid content, M: moisture content.

${ }^{\mathrm{b}}$ Solvent to solid ratio including liquid co-solvents.

c \%vol catalyst with respect to the alkyl donor used. 
Table 6

Acid catalyzed ISTE of microbial biomass.

\begin{tabular}{|c|c|c|c|c|c|c|c|}
\hline Feedstock $\boldsymbol{k}^{\mathrm{a}}$ & Alkyl donor and co-solvent & $\begin{array}{l}S S R^{\mathrm{b}}(\mathrm{ml}: \\
\mathrm{g})\end{array}$ & Catalyst $^{\complement}$ & $\begin{array}{l}T\left({ }^{\circ} \mathrm{C}\right) / P \\
(\mathrm{MPa})\end{array}$ & $t(h)$ & $\% Y_{s}\left(\% Y_{P}\right)$ & Ref. \\
\hline Activated sludge O: n.s. F: n.s. M: 84.5 & Methanol & 30 & $\mathrm{H}_{2} \mathrm{SO}_{4}{ }^{\mathrm{C}}(10 \%)$ & 75/n.s. & 24 & $3.93(\sim 82)$ & [125] \\
\hline $\begin{array}{l}\text { Chlorella vulgaris 0: } 26.9 \text { F: } 3.2 \text { M: n.s. Stirred: } \\
380 \mathrm{rpm}\end{array}$ & Methanol & 7.4 & $\mathrm{H}_{2} \mathrm{SO}_{4}(9.6 \%)$ & $60 / 0.1$ & 20 & $19.4(96.3)$ & [60] \\
\hline Chlorella pyrenoidosa O: 19.6 F: n.s. M: n.s. & Methanol ( $3 \mathrm{ml} / \mathrm{g}$ biomass) & 3 & $\mathrm{H}_{2} \mathrm{SO}_{4}(3.3 \%)$ & $60 / 0.1$ & 4 & $(\sim 48.1)$ & [152] \\
\hline Chlorella pyrenoidosa 0: 56.3 F: n.s. M: n.s. & $\begin{array}{l}\text { Methanol ( } 4 \mathrm{ml} / \mathrm{g} \text { biomass) Hexane }(6 \mathrm{ml} / \\
\mathrm{g} \text { biomass) }\end{array}$ & 10 & $\mathrm{H}_{2} \mathrm{SO}_{4}(2.7 \%)$ & 90/n.s. & 2 & $(95)$ & [153] \\
\hline $\begin{array}{l}\text { Chlorella pyrenoidosa O: } 47 \text { F: n.s. M: 0-90 } \\
\text { Continuously Stirred }\end{array}$ & $\begin{array}{l}\text { Methanol ( } 4 \mathrm{ml} / \mathrm{g} \text { biomass) Hexane }(6 \mathrm{ml} / \\
\mathrm{g} \text { biomass) }\end{array}$ & 10 & $\mathrm{H}_{2} \mathrm{SO}_{4}(1.1 \%)$ & $120-150$ & 2 & $(88-90)$ & [154] \\
\hline \multirow{2}{*}{$\begin{array}{l}\text { Chlorella sp. O: } 27.6 \text { F: } 5.11 \text { M: n.s. Continuously } \\
\text { stirred }\end{array}$} & Methanol ( $4 \mathrm{ml} / \mathrm{g}$ biomass $)$ & 4 & $\mathrm{H}_{2} \mathrm{SO}_{4}(3.7 \%)$ & \multirow[t]{2}{*}{$60 / 0.1$} & 2 & \multirow[t]{2}{*}{$(\sim 86)$} & \multirow[t]{2}{*}{ [155] } \\
\hline & $\begin{array}{l}\text { Methanol ( } 1 \mathrm{ml} / \mathrm{g} \text { biomass) Diethyl ether } \\
\text { ( } 1 \mathrm{ml} / \mathrm{g} \text { biomass })\end{array}$ & 2 & $\mathrm{H}_{2} \mathrm{SO}_{4}(7.3 \%)$ & & 8 & & \\
\hline \multirow{2}{*}{$\begin{array}{l}\text { Chlorella sp. O: } 27.6 \mathrm{~F}: 5.11 \mathrm{M} \text { : n.s. Ultrasound } \\
\text { assisted }(24 \mathrm{kHz})\end{array}$} & Methanol ( $4 \mathrm{ml} / \mathrm{g}$ biomass) & 4 & $\mathrm{H}_{2} \mathrm{SO}_{4}(3.7 \%)$ & \multirow[t]{2}{*}{$60 / 0.1$} & 0.5 & $(96)$ & \multirow[t]{2}{*}{ [115] } \\
\hline & $\begin{array}{l}\text { Methanol ( } 1 \mathrm{ml} / \mathrm{g} \text { biomass) Diethyl ether } \\
(0.67 \mathrm{ml} / \mathrm{g} \text { biomass })\end{array}$ & 1.67 & $\mathrm{H}_{2} \mathrm{SO}_{4}(8.8 \%)$ & & 2 & (99) & \\
\hline Nanochloropsis sp. O: 19.7 F: n.s. M: 65 & $\begin{array}{l}\text { Methanol ( } 5 \mathrm{ml} / \mathrm{g} \text { biomass) Chloroform } \\
\text { (10 ml/g biomass) }\end{array}$ & 15 & $\mathrm{H}_{2} \mathrm{SO}_{4}(10 \%)$ & 95/n.s. & 1.5 & $(\sim 90)$ & [156] \\
\hline Rhodosporidium toruloides $0:$ 58-59 F: n.s. M: - & Methanol & 20 & $\mathrm{H}_{2} \mathrm{SO}_{4}(\sim 1.0 \%)$ & $70 / 0.1$ & 20 & $48.41(94.16)$ & [157] \\
\hline Lipomyces starkeyi O: 50.2 F: n.s. M: - & & & & & & $48.59(96.02)$ & [158] \\
\hline Mortierella isabellina 0: 53.2 F: n.s. M: - & & & & & & $56.90(97.30)$ & [158] \\
\hline
\end{tabular}

n.s.: not specified.

${ }^{\text {a }} \mathrm{O}$ : oil content, F: free fatty acid content, M: moisture content.

b Solvent to solid ratio including liquid co-solvents.

c \%vol catalyst with respect to the alkyl donor used.

Table 7

Base catalyzed ISTE of agricultural biomass.

\begin{tabular}{|c|c|c|c|c|c|c|c|}
\hline Feedstock $^{\text {a }}$ & Alkyl donor and co-solvent & $\begin{array}{l}S S R^{\mathrm{b}} \\
(\mathrm{ml}: \mathrm{g})\end{array}$ & Catalyst & $\begin{array}{l}T\left({ }^{\circ} \mathrm{C}\right) / P \\
(\mathrm{MPa})\end{array}$ & $t(h)$ & $\% Y_{s}\left(\% Y_{P}\right)$ & Ref. \\
\hline \multirow{2}{*}{$\begin{array}{l}\text { Sunflower seed/cottonseed Stirred: } \\
600 \mathrm{rpm}\end{array}$} & Methanol & 10 & $\mathrm{NaOH}(2.0 \%)^{\mathrm{e}}$ & $60 / 0.1$ & 1 & $(95)$ & \multirow[t]{2}{*}[96,97]{} \\
\hline & Ethanol & 12.8 & $\mathrm{NaOH}(2.0 \%)$ & $80 / 0.1$ & 4 & $(90 / 78)$ & \\
\hline \multirow{2}{*}{$\begin{array}{l}\text { Sunflower seed/cottonseed Ultra- } \\
\text { sound assisted }(24 \mathrm{kHz})\end{array}$} & Methanol & 10 & $\mathrm{NaOH}(2.0 \%)$ & $60 / 0.1$ & 0.33 & (95) & \multirow[t]{2}{*}{ [96] } \\
\hline & Ethanol & 12.8 & $\mathrm{NaOH}(2.0 \%)$ & $80 / 0.1$ & 0.67 & (98) & \\
\hline $\begin{array}{l}\text { Sunflower kernels O: } 45.6 \mathrm{~F}: \text { n.s. } \\
\text { M: } 4.6 \text { Stirred: } 150 \mathrm{rpm}\end{array}$ & $\begin{array}{l}\text { Methanol: Diethoxymethane } \\
\text { (1.75 M ratio) }\end{array}$ & 7.2 & $\mathrm{NaOH}(2.3 \%)$ & $20 / 0.1$ & 0.22 & $43.95(97.7)$ & [151] \\
\hline Cottonseed O: $34.6 \mathrm{~F}: 0.4 \mathrm{M}: 1.9$ & Methanol & 6.26 .4 & $\mathrm{NaOH}(0.06 \mathrm{~N})^{\mathrm{d}} \mathrm{NaOH}(0.1 \mathrm{~N})$ & $\begin{array}{l}60 / 0.140 / \\
0.1\end{array}$ & 3 & $(98)$ & [130] [89] \\
\hline $\begin{array}{l}\text { Soybean O: } 22.6-25.8 \mathrm{~F}: \text { n.s. M: 0.1- } \\
\quad 7.4\end{array}$ & Methanol & $2.4-6.8$ & $\mathrm{NaOH}(0.1 \mathrm{~N})$ & $23 / 0.1$ & $7.8-10$ & $(82.1-99.5)$ & {$[24,58]$} \\
\hline \multirow{3}{*}{$\begin{array}{l}\text { Rapeseed O: } 38.3-48 \text { F: } 0.4 \text { M: } 1.0- \\
\quad 6.7\end{array}$} & \multirow[t]{3}{*}{ Methanol } & 66 & $\mathrm{KOH}(0.09 \mathrm{~N}) \mathrm{NaOH}(0.1 \mathrm{~N})$ & \multirow[t]{2}{*}{$60 / 0.1$} & 63 & \multirow{2}{*}{$\begin{array}{l}(80)(98) \\
(88.8)\end{array}$} & \multirow{3}{*}{$\begin{array}{l}{[140][131]} \\
{[90]} \\
{[129]}\end{array}$} \\
\hline & & 16 & $\mathrm{NaOH}(0.1 \mathrm{~N})$ & & 1 & & \\
\hline & & 12.5 & $\mathrm{KOH}(0.02 \mathrm{~N})$ & $65 / 0.1$ & 1 & $(90)$ & \\
\hline $\begin{array}{l}\text { Palm fiber (mesocarp) 0: } 49 \\
\text { F: } 1.2 \text { M: n.s. }\end{array}$ & Methanol & 5.2 & $\mathrm{KOH}(4.3 \%)$ & $60 / 0.1$ & 9.6 & 47.6 & [141] \\
\hline $\begin{array}{l}\text { Cotton Seed O: n.s. F: n.s. M: n.s. } \\
\text { Stirred: } 600 \mathrm{rpm}\end{array}$ & Methyl Acetate & 13.8 & $\begin{array}{l}\mathrm{S}_{2} \mathrm{O}_{8}^{2-} / \mathrm{ZrO}_{2}-\mathrm{TiO}_{2}-\mathrm{Fe}_{3} \mathrm{O}_{4} \\
(21.3 \%)\end{array}$ & $50 / 0.1$ & 10.8 & $(98.5)$ & {$[62]$} \\
\hline \multirow[t]{3}{*}{$\begin{array}{l}\text { Jatropha curcas L. O: } 33.4-55.3 \\
\text { F: } 0.7-1.9 \text { M: } 1.3-4.1\end{array}$} & Ethanol & 7.57 .0 & $\begin{array}{l}\mathrm{NaOH}(0.02 \mathrm{~N}) \text { CTMAB:NaOH } \\
(1: 1 \mathrm{n} / \mathrm{n}) \mathrm{CH}_{3} \mathrm{ONa}(0.06 \mathrm{~N})\end{array}$ & $30 / 0.1$ & 2.52 & (99.5) (99.9) & [111] [138] \\
\hline & Methanol & 12.7 & $\mathrm{NaOH}(0.1 \mathrm{~N})$ & $60 / 0.1$ & 0.2 & $\sim 48 \%(87.8)$ & {$[114]$} \\
\hline & Methyl Acetate & 11.4 & $\begin{array}{l}\mathrm{NaOH}(0.2 \mathrm{~N}) \mathrm{PEG}: \mathrm{NaOH} \\
(3: 1 \mathrm{n} / \mathrm{n})\end{array}$ & $50 / 0.1$ & 1.5 & 90.9 & [91] \\
\hline
\end{tabular}

a $\mathrm{O}$ : oil content, F: free fatty acid content, M: moisture content.

b Solvent to solid ratio including liquid co-solvents.

c n.s.: not specified.

${ }^{\mathrm{d}}$ Concentration of catalyst in the alkyl donor

e \% wt catalyst with respect to the oil present in the biomass.

Among base catalysts, metal alkoxides such as $\mathrm{CH}_{3} \mathrm{ONa}$ are believed to be better than metal hydroxides This can be seen in the ISTE of Jatropha in Table 6 that proved the superiority of sodium alkoxide catalyst in the reaction time required over the phasetransfer catalyst assisted sodium hydroxide. The use of solid base catalyst $\left(\mathrm{SrO} / \mathrm{SiO}_{2}\right.$ and $\mathrm{Mg}-\mathrm{Zr}$ ) has also been explored but the presence of moisture completely inhibited the reaction in the case of $\mathrm{SrO}-\mathrm{SiO}_{2}[61]$. A constant problem in using solid catalyst for ISTE is the separation of solid and catalyst after reaction. Li [22] employed $\mathrm{Mg}-\mathrm{Zr}$ as solid catalyst and utilized a Soxhlet extractor to carry out the reaction. The setup allowed the extraction of lipids from solid and subsequently converted the extracted lipids in the solvent flask containing the catalyst to FAME. A possible solution to this problem was proposed by Wu et al. [62], with the use of magnetic catalyst $\left(\mathrm{S}_{2} \mathrm{O}_{8}{ }^{2-} / \mathrm{ZrO}_{2}-\mathrm{TiO}_{2}-\mathrm{Fe}_{3} \mathrm{O}_{4}\right)$ allowing the separation of solid catalyst with the aid of a magnetic field. The magnetic catalysts was 
Table 8

Base catalyzed ISTE of microbial biomass.

\begin{tabular}{|c|c|c|c|c|c|c|c|}
\hline Feedstock $^{\text {a }}$ & Alkyl donor and co-solvent & $\begin{array}{l}S S R^{\mathrm{b}} \\
(\mathrm{ml}: \mathrm{g})\end{array}$ & Catalyst & $T\left({ }^{\circ} \mathrm{C}\right) / \mathbf{P}(\mathrm{MPa})$ & $t(h)$ & $\% Y_{s}\left(\% Y_{P}\right)$ & Ref. \\
\hline $\begin{array}{l}\text { Chlorella vulgaris } 0: 26.5-27.3 \mathrm{~F}: 3.0-3.4 \mathrm{M}: \\
\quad \sim 0\end{array}$ & Methanol & 7.4 & $\mathrm{NaOH}(1.83 \mathrm{~N})^{\mathrm{d}}$ & $60 / 0.1$ & 20 & $19.6(96.9)$ & {$[60]$} \\
\hline $\begin{array}{l}\text { Rhodosporidium toruloides } 0: 58-59 \text { F: } \text { n.s. }^{c} \\
\text { M: } 0\end{array}$ & Methanol & 20 & $\mathrm{NaOH}(0.1 \mathrm{~N})$ & $70 / 0.1$ & 10 & $(96.93)$ & [157] \\
\hline $\begin{array}{l}\text { Chlortella vulgaris ESP-31 O: } 22.7 \text { F: n.s. M: } \\
0\end{array}$ & Methanol $(4.9 \mathrm{ml} / \mathrm{g})$ Hexane $(0.55 \mathrm{ml} / \mathrm{g})$ & 5.5 & $\begin{array}{l}\mathrm{SrO} / \mathrm{SiO}_{2} \\
(\sim 25 \%)^{\mathrm{e}}\end{array}$ & $45 / 0.1$ & 6 & $18.5(81.8)$ & [61] \\
\hline Nannochloropsis sp . O: 46.43 F: n.s. M: 4.41 & $\begin{array}{l}\text { Methanol (30 ml/g) Dichloromethane } \\
(15 \mathrm{ml} / \mathrm{g})\end{array}$ & 45 & $\mathrm{Mg}-\mathrm{Zr}(\sim 22 \%)$ & $65 / 0.1$ & 4 & 26.9 & {$[22]$} \\
\hline Nannochloropsis sp O: 45.5 F: n.s. M: 8-10 & Methanol & 9 & $\mathrm{KOH}(4.4 \%)$ & Microwave $400 \mathrm{~W}$ & 0.1 & $(80.1)$ & {$[100]$} \\
\hline
\end{tabular}

a $\mathrm{O}$ : oil content, F: free fatty acid content, M: moisture content.

b Solvent to solid ratio including liquid co-solvents.

c n.s.: not specified.

d Concentration of catalyst in the alkyl donor.

e \% wt catalyst with respect to the oil present in the biomass.

successfully reused for 8 times, maintaining a FAME yield of $\sim 85 \%$ and a catalyst recovery of $\sim 90 \%$ by weight [62].

Disregarding its sensitivity to water and FFA, base catalyst is preferred over acid due to its higher activity, moderate reaction condition needed, and lower corrosion risk than acid catalyst. Larger amounts of alcohols and more base catalyst is also required in ISTE process than the conventional process [57].

\subsubsection{Two-step acid-base catalyzed ISTE/reactive extraction}

Two-step acid-base catalyzed process is a strategy to obtain better FAME productivity from feedstock with high FFA and moisture content. This strategy proceeds by the esterification of FFA with an acid catalyst and then transesterification of the remaining oil in the feedstock. This has also been carried out in conventional biodiesel production but in most cases the esterified products in the first step is firstly allowed to separate from the water produced and then further reacted to completion. Shui et al. [63] introduced a simpler approach using rice bran as the feedstock in which after the esterification step, excess base was directly added to neutralize the acid catalyst and the remaining base catalyst not consumed during neutralization was left to catalyze the second reaction step.

As can be seen in Table 9, this strategy has been successfully applied in the ISTE of feedstock with high FFA and water contents [63-65]. Compared to the single step acid or base catalyzed ISTE, this process can have a wider application due to its better tolerance to FFA and water, and results in high productivity due to the shorter reaction time required. The use of modified Soxhlet to carry out this approach was also successfully done by Lei $[66,67]$ allowing easy separation of solid and products.

However, addition of excess base in the second step is a big drawback in this process. Dong et al. [68] used an approach by applying solid acid catalyst (Amberlyst-15) packed in a fine stainless steel mesh, the by-products from neutralization could be minimized without difficulties in separating and recycling of catalyst. Although this was effectively carried out in lab scale with high catalyst reusability ( 8 batches), an effective design of the reactor should be taken into consideration for effective mixing and contact with the catalyst as it required up to $30 \%$ of catalyst based on biomass weight. This was only applied to a biomass sample having relatively low lipid content $(\sim 12 \%)$ wherein the resulting water due to esterification might be low enough for the base catalyzed reaction. The seemingly disadvantageous neutralization step when utilizing $\mathrm{H}_{2} \mathrm{SO}_{4}$ may actually provide better tolerance to water as the metal sulfates $\left(\mathrm{Na}_{2} \mathrm{SO}_{4}\right.$ or $\left.\mathrm{K}_{2} \mathrm{SO}_{4}\right)$ formed during reaction may act as sorbents for water present in the reaction.

\subsubsection{Enzyme catalyzed ISTE / reactive extraction}

The use of enzyme as catalyst in biodiesel production is not very new but its application to ISTE has only been explored by a few. A summary of these studies is given in Table 10. Unlike acid and base catalyzed ISTE the dominant alkyl donor utilized in enzyme ISTE are alkyl acetates and dialkyl carbonates.

Enzymes are believed to be environmentally benign and capable of achieving high yields of FAME (86-96\%). A major hindrance to its application in industry is its high cost. In order to cut down cost most lipases are typically immobilized in order for ease of recovery and reuse. However, the nature of ISTE processes involves solid biomass as feedstock making a potential problem for separation of the residual biomass and the immobilized lipase. Gao's group [69-71], provided two solutions to this problem: (1) the utilization of indigenous lipase in germinating seed/kernels; (2) the use of catalyst basket made of stainless steel mesh for ease of separation and recovery of the immobilized enzyme. Tran [72] on the other hand immobilized the lipase on Nano $\mathrm{Fe}_{3} \mathrm{O}_{4}-\mathrm{SiO}_{2}$ and recovered the lipase by inducing a magnetic field over the reaction products.

The first alternative seems very promising but it requires a germination period ( $\sim 4$ days) in order to ensure high lipase activity [69]. The second approach seems more practical. The reuse of lipase (lipozyme TL IM) in ISTE process resulted in at least 5 reuse/batches before its activity started dwindling [70]. Lipozyme TL IM has been suggested for utilization in biodiesel production due to its cheaper cost $(\$ 800 / \mathrm{kg})$ compared to the well-studied and widely used Novozym $435(\$ 9500 / \mathrm{kg})$ [70]. The use of lipase immobilized on Nano $\mathrm{Fe}_{3} \mathrm{O}_{4}-\mathrm{SiO}_{2}$ was successfully carried out with high tolerance to moisture $(\sim 71 \%)$ but after the third cycle the activity dropped to less than $80 \%$ of its original activity [72].

Alcohol is required in higher amount than conventional process, which inhibits enzyme activity. In conventional process, a small amount of alcohol is added over the reaction duration to avoid such inhibitory effect, which is not applicable in ISTE. To resolve this problem 2 approaches were proposed: the use of cosolvent [69,71]; and the use of alkyl donor less toxic to lipase.

Gu [69] used hexane $(2.5 \mathrm{~mL} / \mathrm{g}$ seed $)$ as the co-solvent and found that hexane added less than the optimum amount resulted in lower enzyme activity due to lower capacity to extract oil and higher methanol concentration inhibited lipase activity. Excess hexane also resulted in lower activity due to dilution of both oil and methanol leading to slower reaction rate. Jiang [70] explored the use of co-solvents over a solid to solvent ratio (SSR) of 2.5$4.5 \mathrm{ml} / \mathrm{g}$ including $\mathrm{n}$-hexane, tert-butanol, petroleum ether and dichloromethane with Lypozyme TL IM as the catalyst. Hexane ( $3.5 \mathrm{ml} / \mathrm{g}$ ) was found to provide the highest enzyme activity 


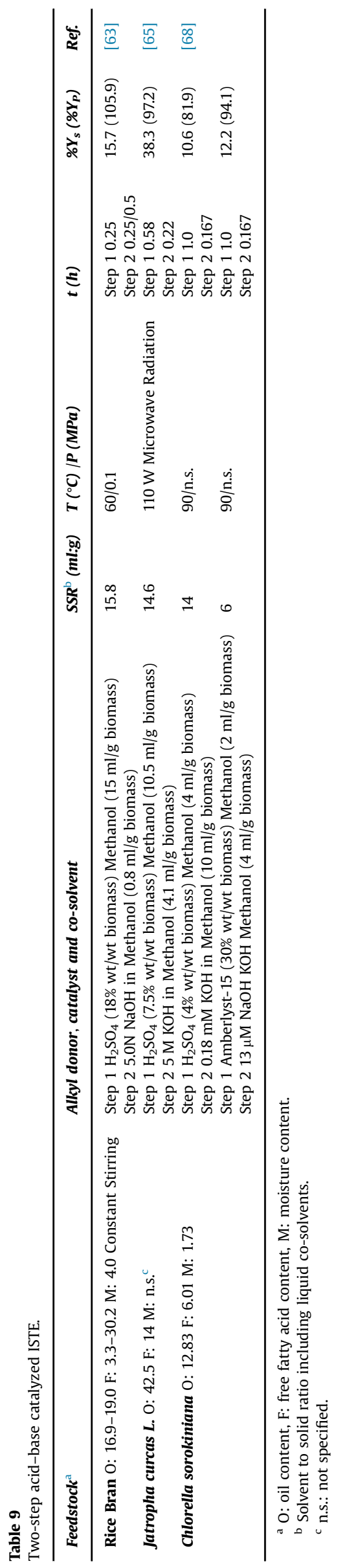

followed by petroleum ether, tert-butanol and dichloromethane. The 2 studies resulted in different optimum hexane to biomass ratio probably due to difference in the lipase used. Other researchers proposed the use of alkyl acetates and dialkyl carbonates, which were found to have comparable oil extraction capacity with hexane $[6,10]$ and at the same time served as the alkyl donor.

Enzyme has been known for its specificity, thus avoiding side reactions. The specificity of an enzyme depends on the nature of the solvent utilized and the characteristic and quality of the substrate. As can be seen from Table 1, substrate with specific amount of water content and oil quality (high FFA or low FFA) with the enzyme utilized would require different amount of alkyl donor. This inherent nature of enzyme might hinder its industrialization due to lack of robustness.

\subsubsection{Supercritical and subcritical ISTE}

Operating temperatures and pressures above the critical points of alcohols or any other alkyl donors were considered to be supercritical and those below the critical point but above their boiling points were taken to be subcritical. Compared to alkyl donors, lipids or oils have much higher critical temperatures $\left(>600{ }^{\circ} \mathrm{C}\right.$ ). Bunyakiat [73] estimated the pseudo critical points of methanol and oil mixture using Berthelot mixing rule and Lydersen's method of group contribution and found that for the entire system to be under supercritical state the temperature and pressure should be over $280^{\circ} \mathrm{C}$ and $6.8 \mathrm{MPa}$, respectively at a methanol to oil molar ratio of 42 . A ratio lower than 42 would require higher temperature for the system to reach pseudo-critical state. This type of estimation was also adopted by Lee and Lim [74] employing Constantinuo-Gani group contribution and assuming that the presence of solid has little or no effect on the estimation. The same approach was also carried out by Go et al. [75] where a mixture of subcritical solvents was used. As a general rule in ISTE due to the large excess of alkyl donors, system with temperature below the alkyl donor's critical point but above its boiling point may safely be assumed as under subcritical state. On the other hand a system with temperature over $300{ }^{\circ} \mathrm{C}$ may be assumed to be at the pseudo-supercritical state, while those between the critical temperatures and below $300{ }^{\circ} \mathrm{C}$ should be further evaluated depending on the reaction mixture involved.

The use of supercritical alcohols in biodiesel production was introduced by Saka [76] in early 2001 and its application in ISTE was first explored in 2010 by Lee and Lim [20] using Jatropha seed and by Levine [77] using Chlorella biomass in 2010. The main objective of using supercritical alcohols was to avoid the use of catalyst and improve the solubility between lipids and alcohols, but in turn required high temperatures and pressures of up to $300{ }^{\circ} \mathrm{C}$ and $20 \mathrm{MPa}$, respectively. Less severe approaches operating under subcritical conditions $\left(T<240{ }^{\circ} \mathrm{C}\right.$ and $P<8 \mathrm{MPa}$ ) of alcohols to produce biodiesel were also investigated. Glisic [78] suggested that the use of subcritical alcohols is less energy efficient as it would require more energy in recovering the excess alcohols introduced to compensate for the lower reaction rate compared to supercritical alcohols. In view of ISTE, the use of excess alcohols or solvents are necessary in order to simultaneously react and extract the available lipids in biomass, thus the use of subcritical solvents may be more applicable in ISTE.

Tables 11 and 12 summarize studies on subcritical and supercritical ISTE. It can be observed that these 2 processes have high tolerance to moisture and FFA contained in the feedstock. The use of sub or supercritical ISTE allows the use of dilute strong acid or weak organic acid under less severe operating conditions and lower catalyst loading; or in a catalyst free process operating under higher temperature and pressure. 
Table 10

Enzyme-catalyzed ISTE.

\begin{tabular}{|c|c|c|c|c|c|c|c|}
\hline Feedstock $\boldsymbol{k}^{\mathrm{a}}$ & Alkyl donor and co-solvent & $\begin{array}{l}S S R^{\mathrm{b}} \\
(\mathrm{ml}: \mathrm{g})\end{array}$ & Catalyst & $\begin{array}{l}T\left({ }^{\circ} \mathrm{C}\right) / \mathrm{P} \\
(\mathrm{MPa})\end{array}$ & $t(h)$ & $\% Y_{s}\left(\% Y_{P}\right)$ & Ref. \\
\hline $\begin{array}{l}\text { Jatropha curcas L. O: } 54.90 \% \mathrm{~F}: \mathrm{n} \text {. } \\
\text { s. }{ }^{\mathrm{c}} \text { M: } 4.62 \%\end{array}$ & $\begin{array}{l}\text { Methyl acetate } \\
\text { Ethyl acetate }\end{array}$ & 7.5 & Novozyme 435 ( $30 \%$ of oil) & $50 / 0.1$ & $24-36$ & $\begin{array}{l}(86.1) \\
(87.2)\end{array}$ & [6] \\
\hline $\begin{array}{l}\text { Pistacia chinensis B. } 0: 36.69 \% \text { F: } \\
\text { n.s. M: } 4.26 \%\end{array}$ & $\begin{array}{l}\text { Methyl acetate } \\
\text { Ethyl acetate }\end{array}$ & & & & & $\begin{array}{l}(92.8) \\
(89.5)\end{array}$ & \\
\hline $\begin{array}{l}\text { Jatropha curcas L. O: } 54.90 \% \mathrm{~F}: \mathrm{n} \text {. } \\
\text { s. M: } 3.02 \%\end{array}$ & $\begin{array}{l}\text { Dimethyl Carbonate } \\
\text { Diethyl Carbonate }\end{array}$ & 10 & Novozyme 435 ( $10 \%$ of oil) & $50 / 0.1$ & $24-36$ & $\begin{array}{l}(95.9) \\
(94.5)\end{array}$ & [10] \\
\hline $\begin{array}{l}\text { Pistacia chinensis B. O: } 36.69 \% \text { F: } \\
\text { n.s. M: } 2.34-3.14 \%\end{array}$ & $\begin{array}{l}\text { Dimethyl Carbonate } \\
\text { Diethyl Carbonate }\end{array}$ & & & & & $\begin{array}{l}(89.6) \\
(90.7)\end{array}$ & \\
\hline $\begin{array}{l}\text { Jatropha curcas L. O: } 54.2 \% \mathrm{~F}: \\
\quad>90 \% \mathrm{M}: 2.9 \%\end{array}$ & $\begin{array}{l}\text { 1.5: } 1 \text { methanol:oil (molar ratio) } \\
\text { Hexane ( } 2.5 \mathrm{ml} / \text { gram seed) }\end{array}$ & $\sim 2.6$ & Indigenous lipase in germinated seeds & $35 / 0.1$ & 8 & (87.6) & [69] \\
\hline $\begin{array}{l}\text { Castor seed O: } 61.23 \% \text { F: n.s. M: } \\
2.11 \%\end{array}$ & Dimethyl Carbonate & 12.5 & & & 8 & $(87.4)$ & [71] \\
\hline $\begin{array}{l}\text { Jatropha curcas L. O: } 54 \% \text { F: } 7.6 \% \\
\text { M: } 0.5-1.0 \%\end{array}$ & $\begin{array}{l}\text { 6:1 methanol:oil (molar ratio) } \\
\text { Hexane ( } 3.5 \mathrm{ml} / \text { gram seed) }\end{array}$ & $\sim 3.8$ & Lipozyme TL IM ( $15 \%$ of oil) & $45 / 0.1$ & 12 & $(90.6)$ & [70] \\
\hline $\begin{array}{l}\text { Chlorella vulgaris } 0: 63.2 \% \mathrm{~F}: \text { n.s. } \\
\text { M: } 71 \%\end{array}$ & $\begin{array}{l}\text { Methanol ( } 2.6 \mathrm{ml} / \mathrm{g} \text { biomass) Hex- } \\
\text { ane ( } 5.2 \mathrm{ml} / \text { gram biomass) }\end{array}$ & 7.8 & $\begin{array}{l}\text { Burkholderia sp. lipase on nano } \mathrm{Fe}_{3} \mathrm{O}_{4^{-}} \\
\mathrm{SiO}_{2}(\sim 200 \% \text { of biomass })\end{array}$ & $40 / 0.1$ & 48 & $56.5(94.2)$ & [72] \\
\hline $\begin{array}{l}\text { Chlorella sp. O: } 40.9 \% \text { F: n.s. M: } \\
0.5 \%\end{array}$ & Dimethyl carbonate & 10 & Novozyme 435 (20\% of biomass) & $70 / 0.1$ & 24 & $36.73(90.5)$ & [159] \\
\hline
\end{tabular}

${ }^{a} \mathrm{O}$ : oil content, F: free fatty acid content, M: moisture content.

b Solvent to solid ratio including liquid co-solvents.

c n.s.: not specified

Table 11

Subcritical and supercritical ISTE using agricultural biomass as feedstock

\begin{tabular}{|c|c|c|c|c|c|c|c|}
\hline Feedstock ${ }^{a}$ & Alkyl donor and co-solvent & $\begin{array}{l}S S R^{\mathrm{b}} \\
(\mathrm{ml} / \mathrm{g})\end{array}$ & $\begin{array}{l}\text { Space loading } \\
(\mathrm{ml} / \mathrm{g})^{\mathrm{d}}\end{array}$ & $\begin{array}{l}T\left({ }^{\circ} \mathrm{C}\right) / P \\
(\mathrm{MPa})\end{array}$ & $t(h)$ & $\% Y_{s}\left(\% Y_{P}\right)$ & Ref. \\
\hline \multirow[t]{4}{*}{$\begin{array}{l}\text { Jatropha curcas L. O: } 64.59-66.82 \% \text { F: } 0-30 \% \\
\text { M: } 0-40 \%\end{array}$} & $\begin{array}{l}\text { Methanol }(4 \mathrm{ml} / \mathrm{g}) / \text { Pentane } \\
(1 \mathrm{ml} / \mathrm{g})\end{array}$ & 5 & 30 & $280 / 10.0$ & $0.5(1.54)^{\mathrm{e}}$ & $(100.4)$ & $\begin{array}{l}{[20,74,79,81,} \\
113,117]\end{array}$ \\
\hline & Methanol $(4 \mathrm{ml} / \mathrm{g}) / \mathrm{CO}_{2}$ (50 bars) & 4 & 30 & $280 / 20.0$ & $0.5(1.54)$ & $(102.3)$ & \\
\hline & Methanol & 5 & 54 & $300 / 9.5$ & $0.5(1.71)$ & (99.67) & \\
\hline & $\begin{array}{l}\text { Methanol }(5.9 \mathrm{ml} / \mathrm{g}) / \mathrm{CO}_{2}(20 \\
\text { bars })\end{array}$ & 5.9 & 30 & $300 / 12.0$ & $0.5(1.71)$ & $(92.0)$ & \\
\hline Jatropha curcas L. O: n.s. ${ }^{\mathrm{C}} \mathrm{F}$ : n.s. M: n.s. & Methanol & 40 & n.s. & $280 / 12.7$ & $0.5(1.33)$ & $(97.9)$ & {$[160]$} \\
\hline Jatropha curcas L. O: $\sim 57 \%$ F: $0-5 \%$ M: $\sim 5 \%$ & $25 \%$ Acetic Acid in Methanol & 7 & 12 & $250 / 10$ & $1.0(1.75)$ & $51.14(88.24)$ & {$[42]$} \\
\hline Stirred continuously & $\begin{array}{l}25 \% \text { Acetic Acid in Methanol } \\
\text { Carbon Dioxide }\end{array}$ & & & $250 / 21$ & & $\begin{array}{l}54.72 \\
(94.43)\end{array}$ & \\
\hline $\begin{array}{l}\text { Jatropha curcas L. O: } \sim 54 \% \mathrm{~F}: 2-25 \% \mathrm{M}: \\
\quad \sim 5 \%\end{array}$ & 10\% Acetic Acid In Methanol & $\begin{array}{l}3 \\
7\end{array}$ & $\begin{array}{l}6 \\
12\end{array}$ & $250 / 10$ & $1.0(1.75)$ & $\begin{array}{l}47.97(88.15) \\
52.90 \\
(97.22)\end{array}$ & [92] \\
\hline $\begin{array}{l}\text { Jatropha curcas L. (Whole kernels) O: } 54.42 \% \\
\text { F: } \sim 2 \% \mathrm{M}: \sim 25 \% \text { Stirred continuously }\end{array}$ & $\begin{array}{l}25 \% \text { Acetic Acid in Methanol } \\
\text { Water }(0.33 \mathrm{ml} / \mathrm{g}) \text { Carbon } \\
\text { Dioxide }\end{array}$ & 7 & 80 & $250 / 12.5$ & $1.0(1.75)$ & $(96.56)$ & [99] \\
\hline Sunflower kernels O: 45.22\% F: 3\% M: 5\% & $\begin{array}{l}\text { 6.25\% Acetic Acid In Methanol } \\
\text { 10\% Acetic Acid In Methanol }\end{array}$ & $\begin{array}{l}7 \\
3\end{array}$ & $\begin{array}{l}12 \\
6\end{array}$ & $250 / 9.5$ & $1.0(1.75)$ & $\begin{array}{l}41.9(92.8) \\
39.5(87.1)\end{array}$ & [92] \\
\hline $\begin{array}{l}\text { Sunflower kernels (Whole kernels) O: } \\
\text { 45.22\% F: 3\% M: 25\% }\end{array}$ & $\begin{array}{l}25 \% \text { Acetic Acid in Methanol } \\
\text { Water }(0.3 \mathrm{ml} / \mathrm{g})\end{array}$ & 7 & 12 & $250 / 10.5$ & $1.0(1.75)$ & $(77.68)$ & \\
\hline $\begin{array}{l}\text { Soybean O: } 23.9 \% \mathrm{~F}: \text { n.s. M: } 1.6 \% \text { Stirring: } \\
\quad 300 \mathrm{rpm}\end{array}$ & $\begin{array}{l}1.2 \mathrm{~N} \mathrm{H}_{2} \mathrm{SO}_{4} \text { Methanol } / \mathrm{CO}_{2} \\
\text { 2.0 } \mathrm{N} \mathrm{H}_{2} \mathrm{SO}_{4} \text { Methanol } / \mathrm{CO}_{2}\end{array}$ & $\begin{array}{l}2.4 \\
1.6\end{array}$ & 13.3 & 121/n.s. & 10 & $(88.3)$ & [80] \\
\hline Rice bran 0: $17.4 \%$ F: $13.2 \%$ M: n.s. & Methanol Carbon Dioxide & 15 & 50 & $300 / 30$ & 0.083 & $9.2(\sim 62.1)$ & [143] \\
\hline Rice bran 0: 17.4\% F: $13.2 \%$ M: n.s. & $\begin{array}{l}\text { Methanol }(1 \mathrm{ml} / \mathrm{g}) \text { Water }(4 \mathrm{ml} / \\
\text { g) Carbon Dioxide }\end{array}$ & 5 & n.s. & $200 / 3.5$ & 3.0 & $(86.3)$ & [161] \\
\hline $\begin{array}{l}\text { Spent Coffee Grounds O: } 14 \% \text { F: n.s. M: n.s. } \\
\text { Methanol: } 10 \mathrm{ml} / \mathrm{min}\end{array}$ & Methanol Carbon dioxide & 10 & 5 & $300 / 10$ & 0.7 & $(93.7)$ & [116] \\
\hline Kapok seed O: $39.4 \%$ F: $9.1 \%$ M: $2.0 \%$ & Methanol & 30 & n.s. & $160 / 3$ & 6 & $30.1(76.3)$ & {$[146]$} \\
\hline
\end{tabular}

a $\mathrm{O}$ : oil content, $\mathrm{F}$ : free fatty acid content, $\mathrm{M}$ : moisture content.

${ }^{\mathrm{b}}$ Solvent to solid (dry) ratio including liquid co-solvents.

c n.s.: not specified.

${ }^{\mathrm{d}}$ Reactor space $(\mathrm{mL})$ required to process a given amount of dry solid (grams).

e Total reaction time including heating time.

In most supercritical ISTE studies, not only alkyl donor at its supercritical conditions was involved but often carbon dioxide was also used. Carbon dioxide is extensively utilized as a green extracting solvent, which aids extraction and improves solubility in ISTE $[74,79,80]$.

For microbial biomass, compared to acid catalyzed reactions operated at moderate to ambient temperature, the use of sub and

supercritical ISTE allows the reaction to reach completion in a much shorter time $(<20 \mathrm{~h})$, despite the presence of high water content (Table 12).

Although sub and supercritical ISTE seem to have better tolerance to water $[42,81,82]$, hydrothermal stability should be taken into consideration. Shin et al. [83] found that fatty acids in general are stable up to $300{ }^{\circ} \mathrm{C}$ at $20 \mathrm{MPa}$ under subcritical water 
Table 12

Subcritical and supercritical ISTE using microbial biomass as feedstock.

\begin{tabular}{|c|c|c|c|c|c|c|c|}
\hline Feedstock $^{\text {a }}$ & Alkyl donor and co-solvent & $\begin{array}{l}S S R^{\mathrm{b}}(m l / \\
g)\end{array}$ & $\begin{array}{l}\text { Space loading } \\
(\mathrm{ml} / \mathrm{g})^{\mathrm{d}}\end{array}$ & $\begin{array}{l}\mathrm{T}\left({ }^{\circ} \mathrm{C}\right) / \mathrm{P} \\
(\mathrm{MPa})\end{array}$ & $t(h)$ & $\% Y_{s}\left(\% Y_{P}\right)$ & Ref. \\
\hline $\begin{array}{l}\text { Activated sludge 0: } 66.6 \% \mathrm{~F}: 20.7 \% \mathrm{M}: \sim 80 \% \\
\text { Stirred Continuously }\end{array}$ & Methanol & 30 & 240 & $175 / 3$ & 8 & $44.6(75.5)$ & [106] \\
\hline \multirow{2}{*}{$\begin{array}{l}\text { Yarrowia lypolitica O: } 58.5 \% \text { F: } 78.98 \% \text { M: } \\
33.3 \%\end{array}$} & Methanol & \multirow[t]{2}{*}{30} & \multirow[t]{2}{*}{240} & \multirow[t]{2}{*}{$175 / 2.3$} & 8 & $38.42(\sim 90)$ & \multirow[t]{2}{*}{ [108] } \\
\hline & $0.2 \% \mathrm{H}_{2} \mathrm{SO}_{4}$ in Methanol & & & & 2 & $\begin{array}{l}38.96 \\
(\sim 90)\end{array}$ & \\
\hline $\begin{array}{l}\text { Scenedesmus abundans O: } 30.46 \% \text { F: n.s. }{ }^{\mathrm{C}} \mathrm{M}: \mathrm{n} . \\
\mathrm{s} .\end{array}$ & $12.7 \% \mathrm{H}_{2} \mathrm{SO}_{4}$ in Methanol & 3 & n.s. & 100/n.s. & 5 & 10.49 & [162] \\
\hline $\begin{array}{l}\text { Chlorella vulgaris O: n.s. F: n.s. M: 80\% Stir- } \\
\text { red Continuously }\end{array}$ & Methanol & 4 & 48 & $175 / 3.5$ & 4 & 29 & [107] \\
\hline $\begin{array}{l}\text { Rhodotorula glutinis 0: } 32 \% \text { F: n.s. M: n.s. } \\
\text { Stirred: } 1000 \mathrm{rpm}\end{array}$ & $\begin{array}{l}0.95 \% \mathrm{H}_{2} \mathrm{SO}_{4} \text { in Methanol }(2 \mathrm{ml} / \mathrm{g}) \\
\text { Chloroform }(4 \mathrm{ml} / \mathrm{g})\end{array}$ & 60 & n.s. & 120/n.s.* & 5 & $30.40(94.57)$ & [163] \\
\hline $\begin{array}{l}\text { Nannochloropsis gaditana O: } 14.26 \% \text { F: n.s. M: } \\
80 \% \text {. }\end{array}$ & Methanol & 30 & 100 & 225/n.s. & 1.5 & $12.27(\sim 86)$ & [164] \\
\hline $\begin{array}{l}\text { Nannochloropsis gaditana O: } 32 \% \text { F: n.s. M: } \\
65 \%\end{array}$ & $\begin{array}{l}30 \% \mathrm{H}_{2} \mathrm{SO}_{4} \text { in Methanol }(8 \mathrm{ml} / \mathrm{g}) \\
\text { Chloroform }(4 \mathrm{ml} / \mathrm{g})\end{array}$ & 12 & n.s. & $125 /$ n.s. & 2.0 & $12.05(>90)$ & [128] \\
\hline \multirow[t]{2}{*}{ Nanochloropsis salina O: 50\% F: n.s. M: 90\% } & \multirow[t]{2}{*}{ Methanol } & 90 & 250 & $255 / 8.3$ & 0.42 & $(85.8)$ & \multirow[t]{2}{*}[100,165]{} \\
\hline & & 80 & & $250 / 8.3$ & 0.42 & $(84.2)$ & \\
\hline \multirow{3}{*}{$\begin{array}{l}\text { Nanochloropsis salina O: 50-55\% F: n.s. M: } \\
\text { 0-60\% }\end{array}$} & \multirow[t]{3}{*}{ Ethanol } & 12 & n.s. & $265 / 8.0^{*}$ & 0.33 & $\sim 32$ & \multirow[t]{3}{*}[101,104,166]{} \\
\hline & & 30 & & & & 28.9 & \\
\hline & & 22.5 & 250 & $265 / 9.0$ & & $(\sim 67)$ & \\
\hline
\end{tabular}

a: oil content, F: free fatty acid content, M: moisture content.

b Solvent to solid (dry) ratio including liquid co-solvents.

c n.s.: not specified.

${ }^{\mathrm{d}}$ Reactor space $(\mathrm{mL})$ required to process a given amount of dry solid (grams). *Microwave radiated heating.

Table 13

Two-step subcritical and supercritical ISTE.

\begin{tabular}{|c|c|c|c|c|c|c|c|}
\hline Feedstock $^{\text {a }}$ & Alkyl donor and co-solvent & $\begin{array}{l}S S R^{\mathrm{b}}(\mathrm{ml} / \\
\mathrm{g})\end{array}$ & $\begin{array}{l}\text { Space loading ( } \mathrm{ml} / \\
\mathrm{g})^{\mathrm{d}}\end{array}$ & $\begin{array}{l}T\left({ }^{\circ} \mathrm{C}\right) / \mathrm{P} \\
(\mathrm{MPa})\end{array}$ & $t(h)$ & $\% Y_{s}\left(\% Y_{P}\right)$ & Ref. \\
\hline $\begin{array}{l}\text { Jatropha curcas } \text { L. O: } 62.83 \% \text { F: } 3.64 \% \text { M: } \sim 60 \% \text { Stir- } \\
\text { red Continuously }\end{array}$ & $\begin{array}{l}25 \% \text { Acetic Acid in Methanol } \\
\text { Carbon Dioxide }\end{array}$ & 7.5 & 80 & $250 / 11.0$ & $1.0(1.75)^{\mathrm{e}}$ & 65.1 101.7) & [82] \\
\hline Chlorella vulgaris O: $82.8 \% \mathrm{~F}: \sim 40 \% \mathrm{M}: \sim 46 \%$ & Ethanol & 8.4 & $\sim 50$ & 325/n.s. ${ }^{c}$ & 2.0 & $(66.4)$ & [77] \\
\hline $\begin{array}{l}\text { Chlorella protothecoides } 0: 46-58 \% \text { F: } 22-35 \% \text { M: } 0- \\
9 \%\end{array}$ & Ethanol $11-13 \mathrm{~mol} \% \mathrm{Sc}(\mathrm{OTf})_{3}$ & $\sim 2$ & n.s. & 215/n.s. & 1.0 & $(85-98)$ & [86] \\
\hline Chlorella protothecoides 0: $58 \% \mathrm{~F}: \sim 9 \% \mathrm{M}: \sim 7 \%$ & Ethanol & 2.4 & $\sim 50$ & $275 /$ n.s. & 3.0 & (89) & [85] \\
\hline
\end{tabular}

${ }^{a} \mathrm{O}$ : oil content, F: free fatty acid content, M: moisture content.

b Solvent to solid (dry) ratio including liquid co-solvents.

c n.s.: not specified.

${ }^{\mathrm{d}}$ Reactor space $(\mathrm{mL})$ required to process a given amount of dry solid (grams).

e Total reaction time including heating time.

conditions, but unsaturated fatty acids like oleic and linoleic acid should not be exposed to such conditions for over $30 \mathrm{~min}$. Imahara et al. [84] on the other hand recommends biodiesel production under supercritical alcohols to be kept at below $270{ }^{\circ} \mathrm{C}$ to avoid thermal decomposition. Lim and Lee [81] found that methyl linoleate was the least stable, which started decomposing after 20 min of exposure to supercritical methanol at $300^{\circ} \mathrm{C}$.

Apart from the lipids, other biomass components like sugars and proteins are also present in the reaction. Under extreme reaction conditions, side products from these components may be generated and complicate downstream separation and recovery of FAME. No literature has so far looked into this potential problem, especially for sub and supercritical ISTE.

\subsubsection{Two-step sub or supercritical process}

Two-step sub or supercritical ISTE always proceeds firstly with a hydrolysis reaction under subcritical water conditions followed by an in-situ (trans)esterification of the treated biomass in sub or supercritical alcohols. A few studies have so far looked into this approach using microalga biomass [77,85-87] and whole Jatropha curcas kernels [82].

Hydrothermally treated microalga biomass tended to clump together making it easier for separation [77] and during treatment lipids were hydrolyzed into FFA. Treatments were carried out at $215-250{ }^{\circ} \mathrm{C}$ with retention times of $30-60 \mathrm{~min}$ and lipid recovery of $77-90 \%[77,85]$. The treatment of Jatropha kernels was carried out at $175^{\circ} \mathrm{C}$, which resulted in increasing porosity of the kernels allowing the use of whole kernels in the subsequent step, while retaining over $95 \%$ of the lipids [82]. Table 13 shows results of the second step in the two-step ISTE. Common to both groups' results is the increase of lipid content in the treated biomass due to the solubilization of biomass in the aqueous phase.

Hydrothermal treatments of biomass co-produce carbon and nitrogen rich hydrolysates. Hydrolysates from Jatropha kernels were initially investigated to grow yeast and results showed that it is a potential substrate for culturing $Y$. lipolytica [82]. The use of hydrolysates produced from hydrothermal treatment of algae is an adopted idea of using yeast extract to grow yeast and other microorganisms. Levine and colleagues also employed this idea and their results are promising [77,85-87]. Hydrothermal treatment of Nannochloropsis oculata dissolved almost $50 \%$ and $70 \%$ of carbon and nitrogen, respectively of its biomass into the aqueous phase that may be recycled as a sterile nutrient into the algae pond [87]. 


\subsubsection{Mechanism of ISTE / reactive extraction}

Several mechanisms have been proposed for ISTE. Harrington and D'Arcy-Evans $[16,18]$ discovered that higher yields by ISTE was due to the esterification of bound lipids and esterified lipid components had better solubility in acidic alcohol. Kildiran [88] investigated ISTE of soybean oil with various alcohols and found better solubility of acylglycerides (AG) in long chain alcohols, thus suggesting the process to proceed by successive dissolution and alcoholysis of AG. Haas et al. [58] and Qian et al. [89] reported that the presence of alkaline catalyst destroyed intracellular compartments, thus releasing AG and allowing its solubilization and subsequent transesterification.

Through lipid staining (Sudan Black B) and careful observations under a light microscope, Zakariah and Harvey [90] found that cell walls of rapeseed were basically intact during alkaline ISTE and suggested that the reaction involves diffusion of methanol through cell wall and reacts with the intact oil bodies. On the contrary, Kasim [91] utilized Jatropha kernels observed diminishing intact cells through staining. Considering that FAME yield and lipid content of the seeds used in both studies were very similar, such big observed difference may be the result of reaction time required which was about $0.2 \mathrm{~h}$ for Jatropha kernels and about $1 \mathrm{~h}$ for rapeseed (Table 7 ). This means that diffusion, successive dissolution and breaking down of cell walls are all involved in ISTE but to a different degree depending on the characteristic of the biomass involved.

For enzyme catalyzed ISTE, immobilized enzymes are often employed requiring the extraction of cellular lipids first followed by transesterification of the lipids in bulk solvent. Except for those employing indigenous lipase found in oil seeds, reactions occur within the biomass and followed by diffusion of the esterified products to the bulk solvent [69]. The use of solid catalyst or heterogeneous catalyst and approaches where catalyst is not in direct contact with lipid inside the biomass follows similar scheme to that of immobilized enzymes.

Subcritical and supercritical ISTE is believed to involve extraction followed by reaction due to improved solubility of lipids in the alkyl donors or solvents. Since sub and supercritical may proceed with and without catalyst, (trans)esterification may well occur also within the biomass. This was observed in the subcritical ISTE study of Sutanto et al. [92] where whole sunflower kernels were utilized and a mixture of FAME and unreacted AG were still found in the solid residue. Solubilization and breakdown of biomass releasing the lipids could be possible since only about $10 \mathrm{wt} \%$ of the initial biomass was left after the reaction [79]. It was also observed that higher FAME yield was obtained from Jatropha kernels than sunflower kernels under the same reaction conditions despite the fact that Jatropha contains relatively higher lipids [92].

The use of the term in-situ transesterification (ISTE) is somewhat ambiguous. In-situ means "in position" or "in place". Therefore technically speaking, only those that involve (trans)esterification reactions within biomass and simultaneously extract the reaction products and/or lipid constituents or undergo reactive extraction are true ISTE. While those processes that sequentially carry out extraction and (trans)esterification, having a distinct extraction step prior to the reaction are single-step (trans)esterification processes or pseudo-ISTE but not ISTE, since the reaction does not occur in place or inside the biomass.

\subsection{Comparison of different ISTE processes (process variables)}

Each process has certain advantages and disadvantages. Some of these advantages may bring certain disadvantages and vice versa. Thus it is better to look into specific process variables and indicators so to take better advantage of the available technologies in situations they are most favorable. Apart from the process indicators described in Section 2.1 to assess process efficiency, it is also important to look into the severity of the process parameters which may directly or indirectly affect the efficiency and the overall process productivity.

\subsubsection{Size reduction and pretreatment/conditioning of biomass}

Since ISTE involves the direct utilization of oil bearing biomass, the particle size of biomass plays a major role in the reaction rate [90]. Grinding of rapeseed to $300-500 \mu \mathrm{m}$ resulted in a shorter reaction time $(1 \mathrm{~h})$ than that with a size of $1000-1400 \mu \mathrm{m}(3 \mathrm{~h})$ in a alkaline ISTE [90]. For supercritical ISTE using Jatropha seeds [20], small particle size generally resulted in higher yields and faster reaction rates but particle size $<500 \mu \mathrm{m}$ resulted in lower yields. Fine particles with high lipid content tend to agglomerate and reduce effective surface area, thus a particle size of 500 $1000 \mu \mathrm{m}$ is recommended for supercritical ISTE of Jatropha kernels [20]. Sutanto et al. [92] investigated ISTE of sunflower and Jatropha kernels, which were grounded to similar size and reacted under the same conditions. Despite containing higher extractable lipids Jatropha kernels resulted in higher yield (based on extractable lipid). The authors speculated that biomass composition might have influenced the process where Jatropha kernels were found to have lower lignin content, which require shorter time to breakdown the solid matrix leading to easier penetration of solvents and faster extraction. From the above discussion, the particle size required depends on the ISTE process involved, characteristic of the biomass and its lipid content.

Apart from grinding to reduce the particle size, homogenizers $[18,93]$ and ultrasonic probes [94] are widely used to break down cell walls and reduce the particle size. Various methods like extrusion and pulse wave treatment [95], hydrothermal pretreatment [77,85-87], maceration [53,96,97] were also explored to provide efficient extraction. All the above treatments or conditioning methods tend to be energy intensive and require additional processing time. Except for hydrothermal treatments (Section 3.3.6), most other treatments do not produce useful side products to compensate for the cost incurred. In separate studies Go et al. $[82,92,98,99]$ provided alternative routes to directly utilize whole seed kernels, which avoid the need to reduce particle size.

\subsubsection{Temperature and heating (convective and microwave assisted)}

Reaction temperature is an important indicator of the severity of a process. Generally catalyzed reactions are carried out between room temperature and boiling point of the alkyl donor. Most catalyst may be applied at high temperature except for enzyme and solid catalyst which need consideration on their thermal stability. Depending on reaction mixture, ISTE carried out at $120-280{ }^{\circ} \mathrm{C}$ is considered as subcritical and above $280^{\circ} \mathrm{C}$ as supercritical. Higher temperature is often associated with better solubility, faster reaction rate, less or no catalyst requirement but higher energy consumption and more severe process conditions.

Most ISTE processes involve direct heating such as resistive heating. Another form of heating is through microwave irradiation, which has been applied to base [100], two-step acid-base [65] catalyzed reactions and to supercritical alcohol conditions [101]. Microwave heating can either be constant irradiation [65,100,102] or temperature controlled irradiation $[101,103,104]$. Compared to microwave irradiation, conventional heating has a few drawbacks, such as heterogeneous heating of the surface, limitations by the thermal conductivity of material, specific heat, and density $[65,105]$. Microwaves can easily penetrate cell walls providing the energy required for (trans)esterification [100], rapid heating also generates temperature and pressure gradients, assisting the breakdown of cellular walls and enhancing mass transfer and improving reaction rate $[65,104]$. However, scaling up of 
microwave irradiated process may be limited by the availability of material for construction, specific design data and process safety.

\subsubsection{Solvent to solid ratio}

Common alkyl donors utilized in ISTE are summarized in Table 4. Since alkyl donor acts as solvent so excess amount is introduced in the reaction mixture. Unlike conventional process, in ISTE the amount of alkyl donor added is often expressed as solvent to solid ratio (SSR) instead of solvent to oil ratio (SOR). SOR may be more appropriate when used to compare solvent loading between ISTE processes of different or the same feedstock, while SSR is more limited to comparison between the same feedstock. This is mainly due to difference in the lipid content of feedstock. Besides it is also difficult to use the optimum SOR obtained from one feedstock with high lipid content to a feedstock with a lower amount of lipid since the solvent introduced based on the available lipid may not be sufficient to submerge the solid particles, and provide an environment for ISTE. Although it is important that enough solvent is introduced to the system, it should also be noted that excess amounts or high SSR may result in dilution of the system and a lower reaction rate $[6,10,42,75]$. Apart from using SSR as the parameter for comparison between different ISTE, SSR has a strong implication on the overall productivity of a process.

SSR of an ISTE process depends mainly on the oil content of the biomass, capacity of the biomass to absorb solvent, density and morphology of the biomass. Besides biomass characteristics, other reaction constituents also affect SSR which include: the use of cosolvent, catalytic-solvents or phase-transfer-catalyst. Properties of common co-solvents and catalytic-solvents utilized in ISTE are summarized in Tables 14 and 15, respectively. For co-solvents it can be classified into gas and liquid co-solvents. The use of cosolvents is mainly to improve the solubility between oil and alkyl donor, especially alcohols thus improving the reaction rate. Often overlooked is the fact that co-solvent is usually added at a fixed amount of alkyl donor, which actually results in higher overall SSR. Only when gas co-solvent like $\mathrm{CO}_{2}$ is utilized, the apparent SSR remains unchanged. Thus a good co-solvent is one which allows the reduction of alkyl donor while maintaining or lowering the SSR. But it should be taken into consideration that co-solvent does not participate in the reaction and its quantity in the system remains the same while alkyl donor is being consumed thus resulting in the dilution of reaction mixture which is also true when excess amounts of co-solvent is added [69]. Cost, environmental hazard and toxicity of co-solvent should also be taken into account in the choice of co-solvents.

The selection of co-solvents and catalytic-solvents may initially be evaluated by considering the dielectric constants and octanolwater partition coefficients. These measures allow one to evaluate how good a solvent might help in the dissolution of oil and alcohol.
These properties are strong functions of temperature. The dielectric constant of sub/super-critical water for instance decreases with temperature and approaches the dielectric constant of acetone, a solvent known to have good solubility with oils. Apart from improved solubility, water is found to exhibit catalytic properties due to release of ionic species at temperatures from $175^{\circ} \mathrm{C}$ to $250{ }^{\circ} \mathrm{C}$ $[38,45,52]$. Ju et al. [37] proposed using water as co-solvent and catalyst in biodiesel production and applied it in ISTE of wet activated sludge [106], microalgae [107] and yeast [108]. Another catalytic-solvent explored is acetic acid which has been employed in biodiesel production using pure oils [75] and in ISTE [42,82]. Acetone on the other hand is another potential solvent which has not been explored as catalytic-solvent in ISTE. Acetone above its critical temperature was found to possess catalytic activity and was able to form solketal through ketalyzation of glycerol [109]. As a cosolvent acetone has recently been successfully utilized in conventional base-catalyzed transesterification [110]. This maybe potentially adopted in ISTE to act as a catalytic-solvent and reduce glycerol productions.

Hailegiorgis et al. [111,112] employed cetyltrimethylammonium bromide and benzyltrimethylammoniumn hydroxide as phasetransfer catalyst (PTC) in base catalyzed ISTE. The ability to form soluble complexes is the key mechanism of trans esterification reaction in the presence of PTC and a base catalyst [112]. The base catalyst forms reactive metal alkoxide with alcohol, which further forms complex with the cation of PTC. This catalytic complex dissolves more easily in oil and reacts with TG to produce biodiesel. The free PTC cation then complexes with DG creating a second active complex which then moves back to the alcohol phase to allow DG to react and convert oil to biodiesel and glycerol completely.

The use of co-solvents, catalytic-solvents and PTC are aimed to reduce the amount of alkyl donor needed, improve FAME yield and

Table 15

Properties of some catalytic-solvents in ISTE.

\begin{tabular}{|c|c|c|c|}
\hline Co-solvents & Water & Acetic acid & Acetone \\
\hline MW (g/mol) & 18.02 & 60.05 & 58.08 \\
\hline Density (g/ml) @ $25{ }^{\circ} \mathrm{C}$ & 0.998 & 1.045 & 0.791 \\
\hline$T_{b}\left({ }^{\circ} \mathbf{C}\right)$ & 100 & 118 & 56 \\
\hline$T_{c}\left({ }^{\circ} \mathbf{C}\right)$ & 373.9 & 318.8 & 235 \\
\hline$P_{c}(\mathrm{MPa})$ & 22.01 & 5.786 & 4.8 \\
\hline$V_{c}(\mathrm{ml} / \mathrm{mol})$ & 229 & 179.7 & 209 \\
\hline$H_{v a p}(\mathrm{~kJ} / \mathrm{mol}) @ 25{ }^{\circ} \mathrm{C}$ & 40.68 & 23.7 & 31.3 \\
\hline Flash Point $\left({ }^{\circ} \mathrm{C}\right)$ & - & 40 & -20 \\
\hline Viscosity (mPa s) @ $25^{\circ} \mathrm{C}$ & 1.002 & 1.131 & 0.295 \\
\hline $\log P @ 25^{\circ} \mathrm{C}$ & - & -0.30 & -0.042 \\
\hline Dielectric constant @ $20^{\circ} \mathrm{C}$ & 80 & 6.2 & 21 \\
\hline$L D_{50}(\mathrm{~g} / \mathrm{kg})$, oral, rat & - & 3.31 & 3 \\
\hline
\end{tabular}

Table 14

Properties of co-solvents employed in ISTE.

\begin{tabular}{|c|c|c|c|c|c|c|c|c|}
\hline Co-solvents & Carbon Dioxide & Diethyl ether & THF & Hexane & Pentane & Dichloromethane & Chloroform & Diethoxymethane \\
\hline MW (g/mol) & 44.01 & 74.12 & 72.11 & 86.18 & 72.15 & 84.93 & 119.4 & 104.2 \\
\hline Density (g/ml) @ $25^{\circ} \mathrm{C}$ & - & 0.713 & 0.889 & 0.655 & 0.626 & 1.132 & 1.475 & 0.831 \\
\hline$T_{b}\left({ }^{\circ} \mathrm{C}\right)$ & - & 34.6 & 66.0 & 68.0 & 36.1 & 39.6 & 61.15 & $87-88$ \\
\hline$T_{c}\left({ }^{\circ} \mathrm{C}\right)$ & 30.97 & 192.7 & 267.1 & 234.5 & 196.6 & 237 & 264 & 259 \\
\hline $\boldsymbol{P}_{\mathrm{c}}(\mathrm{MPa})$ & 7.374 & 3.600 & 5.190 & 3.020 & 3.370 & 6.080 & 5.328 & 3.29 \\
\hline$V_{c}(\mathrm{ml} / \mathrm{mol})$ & 94 & 280 & 224 & 368.4 & 311 & 185 & 239 & \\
\hline$H_{v a p}(\mathrm{~kJ} / \mathrm{mol}) @ 25^{\circ} \mathrm{C}$ & - & 27.25 & 32.00 & 31.54 & 26.2 & 28.6 & 31.4 & 31.5 \\
\hline Flash Point $\left({ }^{\circ} \mathrm{C}\right)$ & - & -45 & -14.5 & -22.5 & -49 & -14 & & -6 \\
\hline Viscosity (mPa s) @ $25^{\circ} \mathrm{C}$ & - & 0.234 & 0.48 & 0.326 & 0.23 & 0.41 & 0.542 & 0.44 \\
\hline $\log P @ 25^{\circ} \mathrm{C}$ & - & 0.83 & 0.53 & 3.764 & 3.255 & 1.25 & 1.97 & 0.89 \\
\hline Dielectric constant @ $20{ }^{\circ} \mathrm{C}$ & - & 4.34 & 7.6 & 1.89 & 1.844 & 8.93 & 4.807 & - \\
\hline $\boldsymbol{L} \boldsymbol{D}_{\mathbf{5 0}}(\mathrm{g} / \mathrm{kg})$, oral, rat & - & 1.215 & 1.65 & 25 & 5 & 1.25 & 1.25 & 3.2 \\
\hline
\end{tabular}


lower process severity. An important parameter to be considered is the overall loading of solvent in order not to result in a low overall process productivity.

\subsubsection{Reactor loading, space loading and system pressure}

For a chemical process, use of a reactor's available volume is often maximized within a safe limit. In ISTE, reactor loading is usually not a concern as long as adequate mixing can be achieved. For subcritical and pseudo supercritical ISTE, reactor loading is a concern as it will affect the amount of solvent present in the liquid phase. This is because some solvent will be in the void space as vapor; the amount of vapor depends on temperature, pressure and reactor loading.

Space loading, defined as the ratio of reactor volume to the amount of biomass loaded into the reactor, was first introduced by Lim and Lee [113]. It was used to determine the space available for solid biomass to effectively interact with solvent and provides an indirect means of measuring the reactor space available for the expansion of solvents during heating.

Lim and Lee [113] found that extraction yield was insignificantly affected by space loading while FAME yield was significantly affected. In their study, a $450 \mathrm{~mL}$ reactor was utilized. Lowering space loading from $90.0 \mathrm{~mL} / \mathrm{g}$ to $54.0 \mathrm{~mL} / \mathrm{g}$ resulted in an increase in FAME yield, but apparent drop in FAME yield was observed when space loading was decreased to between 36.0 and $18.0 \mathrm{~mL} / \mathrm{g}$. As space loading was decreased from $90.0 \mathrm{~mL} / \mathrm{g}$ to $18.0 \mathrm{~mL} / \mathrm{g}$, an increase in pressure from $9 \mathrm{MPa}$ to $25 \mathrm{MPa}$ was observed. They suggested that a lower space loading might have resulted in higher diffusion and mass-transfer resistances due to higher solid to solvent ratio. Low FAME yield at high space loading $(90.0 \mathrm{ml} / \mathrm{g})$ may be due to low operating pressure exerted by methanol.

In another study, Go et al. [42] varied space loading from 80 to $12 \mathrm{~mL} / \mathrm{g}$ and suggested that lower space loading is preferred as this means better utilization of the reactor's available volume. Moreover as space loading is decreased, the space available for the solvent to expand also is decreased thus resulting in a self-induced pressure, eliminating the need of gas co-solvents to pressurize the system to attain sub/super-critical state. Go et al. [42] also observed a dilution effect in subcritical ISTE when too much solvent was used. This was verified in a separate study on the transesterification of pure oils [75].

A higher space loading indirectly implies a lower solid loading and a bigger space for expansion and vice versa. Instead of space loading, Go et al. [42] used reactor loading to describe the fraction of the reactor's volume occupied by the reacting mixture to provide a direct insight on how effective the reactor is used.

Whether space loading or reactor loading is employed to describe the reaction system, the available space for solvent vapor plays an important role. Studies carried out with sub or supercritical solvents and co-solvents should always consider maximizing the use of reactor volume without compromising safety.

\subsubsection{Modes of mixing (mechanical and ultrasound assisted)}

In ISTE reactions adequate mixing is required to provide a homogeneous mixture of liquid solvent and solid biomass. Mixing may be provided mechanically or via sonication. Mechanically agitated reactions can be done by using magnetic stirrer, mechanical impellers, incubator shakers, etc. Most commonly used in lab scale experiments are magnetic stirrers, whose mixing intensity are often calibrated for low viscosity materials. A major disadvantage of such mixing apparatus is its inability to provide or maintain the desired mixing rate or intensity for viscous liquid or mixture of liquid and solid with high solid loading. Shakers may provide better control of mixing intensity but may not provide adequate mixing for high solid loading samples. Mechanical impellers are most effective as it is capable of maintaining and providing the desired mixing intensity. Different impellers can be used to ensure adequate mixing. Due to the challenges in mixing, studies in ISTE often limits mixing at a certain intensity or power, simply to ensure that solids are well suspended in the reaction solvent. A few studies in ISTE have investigated mixing and found that $300 \mathrm{rpm}$ of mixing (orbital shaker) is adequate to promote adequate distribution of seed particles in the reactor [114]. For reactions under supercritical conditions, mixing may not be necessary [113], while those carried out near critical or in subcritical conditions, mixing may or may not be necessary, but mixing of the reaction mixture may result in shorter reaction time and reduced SSR [42].

Sonication may be carried out directly through the use of an ultrasound probe or horn [115] and indirectly using an ultrasonic bath [56]. Its application resulted in the reduced reaction time $[56,96,115]$, due to improved mass transport between solid and liquid. This results from acoustic streaming where solvent momentum increases as it absorbs the energy from propagating sound waves. Cavitation due to implosion of bubbles formed by the waves results in surface erosion of the solid, deformation and defects within the solid, resulting in further particle size reduction and enhanced reactivity [56]. Most ultrasound assisted ISTE are carried out at low frequency $(24-35 \mathrm{kHz})$ with varying power of $200-500 \mathrm{~W}[56,96,115]$. Sonication may have difficulties in scaling up, to maintain a specific area of exposure to the ultrasound waves.

\subsubsection{Operating modes (batch or continues)}

Most researches on ISTE were carried out in batch mode. Batch is the preferred operating mode since the reaction involves large quantity of solid. The main disadvantage of batch reactions is the start-up and the subsequent down time to remove the reactants and products after reaction. The use of continuous reactor may be realized for microbial biomass. By using high SSR to well disperse the biomass, it can be pumped through a continuous reactor.

Calixto et al. [116] carried out ISTE of spent coffee ground using a semi-continuous system. Supercritical methanol $(10 \mathrm{~mL} / \mathrm{min})$ was continuously pumped through $1.0 \mathrm{~g}$ of spent coffee ground for about $40 \mathrm{~min}$. This semi-continuous process ensured efficient lipid extraction and simultaneous separation of biomass and products, at the expense of using higher solvent amount.

\subsubsection{Catalyst loading, reaction time and process productivity}

Catalyst loading and reaction time vary widely and are greatly affected by other process parameters (Tables 5-13). For catalyst loading involving soluble catalyst (acid/base), they are either expressed as wt\% based on the available oil or biomass used or as concentration in the alkyl donor. Enzyme and solid catalyst are expressed as weight fractions of the available lipids/oils to be (trans)esterified. Generally the use of strong base or acid as catalyst requires less amount than enzyme and solid catalyst.

Since catalyst interacts directly with the available main reactant (lipids or oils) it is normally preferred that catalyst loading is expressed with respect to the available lipids. Considering that in most studies the amount of alkyl donor or SSR is often varied, it tends to dilute the catalyst concentration as SSR is increased at a fixed catalyst loading with respect to the available lipids. While at a fixed concentration of dissolved catalyst, the increase in SSR also means an increase in the overall catalyst loading. In case a catalyticsolvent like acetic acid is used, it would be difficult to express it with respect to the available lipid as it is also important to take it into account as solvent, so not will result in a very high SSR. There is no consensus on how catalyst loading should be expressed, what matters is to understand how one could affect the other and express it in a way which best describes the system involved.

From the published data, acid catalyzed ISTE have reaction times ranging from 0.5 to $24 \mathrm{~h}$, while base catalyzed reactions 
have relatively shorter time of $15 \mathrm{~min}$ to $20 \mathrm{~h}$. Combining both acid and base catalyst in a two-step process results in an improved reaction time which are generally less than $1.5 \mathrm{~h}$. The use of enzymes like lipase as catalyst requires a reaction time of 8-36 h.

Sub and supercritical processes on the other hand require reaction times varying from $30 \mathrm{~min}$ to $8 \mathrm{~h}$, which is similar to that in acid or base catalyzed reactions. One important consideration for sub and supercritical ISTE is the heating time and rate of heating. In some studies these are neglected since small reactors fabricated from stainless steel tubing and fittings were used [77,85,86]. Lab scale reactors (capacity $250-450 \mathrm{~mL}$ ) require $40-90 \mathrm{~min}$ of heating time to reach the desired temperature and normally have a heating rate of $4-5^{\circ} \mathrm{C} / \mathrm{min}[20,42,52,74,75,79,81,82,113,117,118]$.

Although a short reaction time is preferred it should be noted that other parameters especially SSR and reactor loading must also be optimized to provide high productivity. Process productivity is seldom considered in the study of ISTE but is of great importance in the scale-up and design of the overall process as it would later affect the overall economy of the production plant.

\section{Process economy (products and byproducts)}

Data provided by the U.S. Department of Energy [119] shows that biodiesel in U.S. in June 2005 was sold at $\$ 3.4$ per gallon $(\$ 0.89 / \mathrm{L})$ while diesel was sold at $\$ 2.8$ per gallon $(\$ 0.74 / \mathrm{L})$. The fuel prices peaked in June 2008 to $\$ 4.9$ and $\$ 4.6$ per gallon $(\$ 1.29 / \mathrm{L}$ and $\$ 1.22 / \mathrm{L}$ ) for biodiesel and diesel, respectively, but was at their lowest (\$3.2/gallon and $\$ 2.2 /$ gallon or $\$ 0.85 / \mathrm{L}$ and $\$ 0.58 / \mathrm{L}$ ) in April 2009, which could be due to the discovery of oil-shale. The fuel prices have since increased and have been in the range of $\$ 4.2$ to $\$ 4.5$ per gallon ( $\$ 1.10$ to $1.20 / \mathrm{L}$ ) for biodiesel and $\$ 3.8$ to $\$ 4.2$ ( $\$ 1.00$ to $1.10 / \mathrm{L}$ ) for diesel from 2011 till present with an average difference between the cost of biodiesel and diesel of around $\$ 0.4$ per gallon. Europe on the other hand has an average diesel pump price of $\sim € 1.4 / \mathrm{L}(\$ 1.88 / \mathrm{L})$ from July 2013 till July 2014 as reported by Europe Commission-Energy Policy [120].

Many researches have been carried out with regards to ISTE process, but only very few have looked into the techno-economics of ISTE. The process economics not only depends on the process parameters involved, but also on the efficient utilization of feedstock. Besides the main product (biodiesel), the effective utilization of byproducts as an income generating source should lower the biodiesel production cost. Although there is only a limited indepth review regarding ISTE, most authors have agreed that the main challenge lies in the reduction of the alcohol or solvent used in ISTE $[3,121]$.

An article in agricultural research [122] back in 2005 mentioned Haas works on in-situ base catalyzed ISTE of soybean oil $[24,58,59,95]$ and estimated cost of biodiesel produced through the said process was $\$ 3.14 /$ gallon while the cost of diesel was \$3.4/ gallon. The high cost was due to the excessive amount of methanol employed to overcome the problem associated with the moisture present in soybean flake. Drying of the raw material greatly reduced the amounts of methanol and subsequently the production cost decreased to $\$ 1.02 /$ gallon [122]. Compared to conventional process producing biodiesel from soybean oil $(\$ 2.0 / \mathrm{gal})$ it has a lower cost as estimated in a detailed process model by Haas et al. [26]. In their analysis it stated that about $88 \%$ of the cost in biodiesel production is associated with the oil feedstock.

As discussed in the previous sections, the amount of solvent required depends on the nature of the feedstock such as lipid content. Thus instead of trying to reduce the excessive solvent used in ISTE, some researchers focused trying different feedstock (lipid content) together with process optimization (solvent recovery ratio) to reduce production cost. In the following sections, strategies employed by various researchers to reduce the cost of biodiesel production and the overall economics of ISTE process will be discussed

\subsection{Cost of biodiesel from ISTE}

Economic studies on ISTE reported in literature are summarized in Table 16, only the economics of acid and base catalyzed ISTE have been evaluated.

One of the first attempts to evaluate the ISTE economics was the group of Hernandez [123-126] using municipal wastewater sludge as the feedstock. The advantage of using wastewater sludge as feedstock is its low cost. The main cost of using sludge as feedstock lies in dewatering and drying. In their preliminary study on lipid extraction from municipal sludge the cost of dewatering by centrifugation and drying was estimated to be $\$ 0.43$ and $\$ 1.29$ per gallon of biodiesel produced, respectively based on an average $7 \%$ yield in biodiesel per gram of dry sludge [126]. This was later used to estimate the biodiesel production cost in an ISTE process with sludge as the feedstock, using different yields $~ 10 \%$ [124] and $\sim 4-5 \%$ [125] in their process model. This resulted in different cost estimation since the cost factor was expressed in terms of biodiesel produced and not with respect to the amount of water removed or sludge processed. Applying this factor to biomass with higher lipid content or higher biodiesel yield resulted in an

Table 16

Summary of economic analyses on ISTE processes.

\begin{tabular}{|c|c|c|c|c|}
\hline Feedstock $^{\text {a }}$ & Feedstock price & Annual production & Breakeven price & Ref. \\
\hline $\begin{array}{l}\text { Municipal wastewater sludge } Y_{s}: 10 \% \text { A: Methanol C: } \\
\qquad \mathrm{H}_{2} \mathrm{SO}_{4}\end{array}$ & $\$ 51.72 /$ ton $^{\mathrm{b}}$ & $\begin{array}{l}3.07 \times 10^{5} \mathrm{gal} / \text { year }\left(1.16 \times 10^{6} \mathrm{~L} /\right. \\
\text { year) }\end{array}$ & $\$ 3.23 /$ gal $\$ 0.85 / \mathrm{L}$ & [124] \\
\hline $\begin{array}{l}\text { Activated sludge (5\% moisture) } Y_{s}: 4.79 \% \text { A: Methanol C: } \\
\mathrm{H}_{2} \mathrm{SO}_{4}\end{array}$ & $\$ 24.63 /$ ton $^{\mathrm{b}}$ & $\begin{array}{l}1.47 \times 10^{5} \mathrm{gal} / \text { year }\left(5.59 \times 10^{5} \mathrm{~L} /\right. \\
\text { year) }\end{array}$ & $\$ 7.42 /$ gal $\$ 1.96 / \mathrm{L}$ & [125] \\
\hline $\begin{array}{l}\text { Activated sludge (84\% moisture) } Y_{s}: 3.78 \% \text { A: Methanol C: } \\
\mathrm{H}_{2} \mathrm{SO}_{4}\end{array}$ & $\$ 4.84 /$ ton $^{\mathrm{b}}$ & $\begin{array}{l}1.21 \times 10^{5} \mathrm{gal} / \text { year }\left(4.60 \times 10^{5} \mathrm{~L} /\right. \\
\text { year })\end{array}$ & $\$ 14.48 /$ gal $\$ 3.83 / \mathrm{L}$ & [125] \\
\hline Jatropha curcas L. $Y_{s}: \sim 48.0 \%$ A: Methanol C: $\mathrm{NaOH}$ & $£ 90.0 /$ ton $(\sim \$ 153 /$ ton $)$ & - & $£ 620 /$ ton $(\sim \$ 0.92 / \mathrm{L})$ & [91] \\
\hline Jatropha curcas L. $Y_{s}: \sim 48.0 \%$ A: Methyl acetate C: $\mathrm{NaOH}$ & $£ 90.0 /$ ton $(\sim \$ 153 /$ ton $)$ & - & $£ 8570 /$ ton $(\sim \$ 12.82 / \mathrm{L})$ & [91] \\
\hline Rapeseed $Y_{s}: \sim 34.0 \%$ A: Methanol C: $\mathrm{NaOH}$ & $\$ 250 /$ ton & $\begin{array}{l}5.0 \times 10^{4} \text { ton/year }\left(5.71 \times 10^{7} \mathrm{~L} /\right. \\
\text { year) }\end{array}$ & $\$ 879 /$ ton $\$ 0.77 / \mathrm{L}$ & [129] \\
\hline Rhodosporidium toruloides $Y_{S}:$ A: Methanol C: $\mathrm{H}_{2} \mathrm{SO}_{4}$ & $\begin{array}{l}\$ 2302-3699 / \operatorname{ton}^{\mathrm{c}}(\$ 3410-5480 / \text { ton } \\
\text { MO) }\end{array}$ & $1.0 \times 10^{4}$ ton/year $\left(1.14 \times 10^{7} \mathrm{~L} /\right.$ year $)$ & $\$ 5600 /$ ton $\$ 4.93 / \mathrm{L}$ & [127] \\
\hline
\end{tabular}

\footnotetext{
${ }^{a} Y_{S}$ : yield based on solid biomass, A: alkyl donor, C: catalyst.

${ }^{b}$ Centrifugation cost based on $\$ 0.43 /$ gal of biodiesel and drying cost on $\$ 1.29 /$ gal of biodiesel $[123,124,126]$.

c Based on a 10,000 ton microbial oil annual production with biomass containing $67.5 \%$ lipid.
} 
overestimation of the cost and vice versa. When using dry activated sludge catalyzed by sulfuric acid ( $5 \mathrm{wt} \%$ based on dry sludge) with $15 \mathrm{~mL}$ methanol per gram dry sludge and reacted at $75^{\circ} \mathrm{C}$, a breakeven price of $\$ 3.23 /$ gal $(\$ 0.85 / \mathrm{L})$ was obtained. This is lower than the cost of diesel fuel [124]. An attempt to decrease the cost further through the direct use of wet sludge at a reaction temperature of $60^{\circ} \mathrm{C}$ resulted in an increase in the methanol loading or SSR required to as much as 30 and $25 \mathrm{~mL} / \mathrm{g}$ for wet and dry sludge, respectively. From the 3 different cases utilizing sludge the amounts of methanol vary significantly probably due to difference in sludge characteristics, inducing a great effect on the overall economics of the process. The increase in the amount of methanol required and the lower yield ( $\sim 4 \%$ for wet sludge and $5 \%$ for dry sludge) resulted in an increase of the break-even price ( $\$ 14.48$ for wet sludge and $\$ 7.42$ for dry sludge, per gallon of biodiesel) [125]. In their analysis Revellame et al. [125] suggested that drying of sludge to $50 \%$ moisture will be most economically beneficial and biodiesel yield should exceed $10 \%$ by weight of the feedstock and the annual biodiesel production should be at least $3 \times 10^{5}$ gallons.

Although sludge is a cheaper feedstock, its consistency in terms of lipid or biodiesel yield remains a challenge in commercial production. Other researchers prefer the use of oil seeds such as Jatropha and rapeseed. Jatropha is cheaper than rapeseed since it is non-edible. Considering production stability and availability, rapeseed has advantage since it is a commercial crop. In the economic analysis of Kasim [91] using methanol and methyl acetate as the alkyl donor, it was found that methanol is more economical due to its lower cost. Although oil has better solubility in methyl acetate, catalyst has poor solubility in methyl acetate thus requiring the use of PEG as phase transfer catalyst which resulted in very high price of biodiesel produced. It was also suggested that the use of Jatropha is advantageous over soybean due to its much cheaper price [91]. Rapeseed is an edible oil cheaper than soybean oil and despite being more expensive than Jatropha oil still resulted in lower production cost probably due to the lower catalyst amount required, the difference in production capacity and life span of the production plant. It is also suggested that the recycle ratio or percentage of the methanol recycled should be balanced with the cost of energy required during recovery in order to make a process more competitive [91]. In a lab scale study Qian et al. [89] observed that the amount of recycled methanol utilized also affected biodiesel yield which drastically decreased from $98 \%$ to $25 \%$ when the recycling ratio was increased from 0.1 to 0.7 . This was probably due to the poor quality of the recycled methanol containing excess water, which should be kept low especially for base catalyzed ISTE.

Apart from using oil seeds as feedstock, ISTE of biological refuse (sludge), microorganisms like algae and yeast were also well studied. A detailed economic analysis using Rhodosporidium toruloides biomass as feedstock was done by Koutinas et al. [127], which took into consideration the cost of cultivation and recovery of the yeast. Despite an oil yield of $67.5 \%$ was achieved, the cost of microbial oil is very high even when the cost substrate (glucose) was assumed to be zero (Table 17). The high cost is attributed to the cost of the fermenter [127]. High capital investment to produce microbial oil is the main hindrance to its utilization, making it the most uncompetitive among the feedstock evaluated in terms of biodiesel production cost. It is also suggested that fermentation of microbial biomass should be carried out in fed-batch mode to have better productivity and coupled with recovery and purification of byproduct streams for extracellular products to compensate for the production cost [127].

Among the feedstock evaluated, sludge could be the most promising if lipid and biodiesel yield can be maintained at high levels. Competitiveness of seed oils largely depends on the local availability, price, lipid content, productivity and effective utilization of the spent kernels or seeds after ISTE. While oil of microbial origin requires a cheap and easily available substrate coupled with innovative fermenter design to lower down capital cost. In general a more detailed economic model is required, which incorporates the effects of production scale, biodiesel yield, lipid content, biomass cost, solvent loading and recycling, revenues generated from byproduct streams and treatment of waste streams. In addition, economic analysis of other ISTE (two-step acid-base, enzymatic, sub and supercritical) processes and on feedstock like microalgae and agricultural residues are also worth exploring to better understand what other variables are affecting the production cost of biodiesel production by ISTE. Moreover, a realistic model not to mislead the potentials of each process is required.

\subsection{Products and byproducts}

The main byproduct of biodiesel production is glycerol. In non ISTE processes various byproducts produced due to using different alkyl donors are summarize in Table 4 . These byproducts are by far not quantified nor monitored in ISTE processes, especially those

Table 17

Summary of vegetable oils produced in the world from 1992 to 2012 [135].

\begin{tabular}{|c|c|c|c|c|}
\hline Edible oil & Share on world production (\%) & Top producing countries & Producing region & Share by region (\%) \\
\hline Palm & 31.83 & Malaysia, Indonesia, Nigeria, Thailand Colombia & Asia & 86.1 \\
\hline \multirow[t]{2}{*}{ Soybean } & 26.34 & USA, Brazil, China, Argentina & Americas & 62.7 \\
\hline & & & Asia & 26.6 \\
\hline \multirow[t]{2}{*}{ Rapeseed } & 14.95 & China, Germany, India, Canada & Asia & 47.5 \\
\hline & & & Europe & 36.3 \\
\hline \multirow[t]{2}{*}{ Sunflower } & 9.48 & Russia, Argentina, Ukraine, France, Turkey & Europe & 58.5 \\
\hline & & & Americas & 20.4 \\
\hline Palm Kernel & 3.83 & Malaysia, Indonesia, Nigeria, Brazil Thailand & Asia & 77.5 \\
\hline Cottonseed & 3.36 & China, India, USA, Pakistan & Asia & 71.1 \\
\hline Groundnut & 3.28 & China, India, Nigeria, Myanmar & Asia & 72.7 \\
\hline Olive & 2.11 & Spain, Italy, Greece, Tunisia, Syrian Arab Republic & Europe & 76.5 \\
\hline Coconut & 2.10 & Philippines, Indonesia, India, Viet Nam, Mexico & Asia & 87.4 \\
\hline Corn & 1.49 & USA, China, Japan, South Africa & Americas & 64.7 \\
\hline Sesame & 0.81 & China, Myanmar, India, Sudan & Asia & 81.6 \\
\hline \multirow[t]{3}{*}{ Linseed } & 0.34 & China, Belgium, USA, India & Asia & 35.4 \\
\hline & & & Europe & 33.3 \\
\hline & & & Americas & 24.5 \\
\hline \multirow[t]{2}{*}{ Safflower } & 0.09 & India, USA, Mexico, Japan, Argentina & Americas & 49.6 \\
\hline & & & Asia & 47.0 \\
\hline
\end{tabular}


produced via enzymatic ISTE. By-products like ethyl levulinate, diethyl ether, and ethyl formate were observed in addition to biodiesel during acid catalyzed subcritical ethanol ISTE of wet microalgae in a study by Im et al. [128].

Apart from FAME and byproducts, spent biomass residue is coproduced in ISTE. Residues from oil seeds like soy [122], rapeseed [129], cottonseed [89,130,131] and Jatropha [91] may be used as feed-mix for farm animals and fish as they are rich in protein. When utilizing residue as feed it should be free of toxins like phorbolesters in Jatropha and gossypol in cottonseed.

Utilization as feed-mixes only may not be enough to make ISTE process economically viable. There were reports of producing byproducts such as protein [132] and hydrolysates for fermentation from rice bran [133].

Residue from microbial biomass could also be utilized. Yeshitilla et al. [134] used de-lipid Y. lipolytica cells to produce hydrolysate rich in glucose for ethanol fermentation. Production of low cost substrate from hydrolysate of biomass [77,82,85,87] may also be produced prior to ISTE reactions as mention in Section 3.3.6. In the case of sub and supercritical ISTE, residues may be utilized as solid fuel or explored as basic catalyst and supports [79,99]. Recovery of small amount but high value byproducts such as phenolics, flavonoids and sterols during ISTE process [79,99] may also be taken into consideration to reduce production cost.

\section{Future prospects in biodiesel production}

Our dependence on energy, transportation and machinery are increasing. According to World Bank, the world average road sector diesel consumption per capita in kilogram oil equivalent has increased from $\sim 107$ in 2004 to $\sim 119$ in 2011 while gasoline has since decreased from $\sim 140$ in 2004 to $\sim 135$ in 2011 . The net calorific value of gasoline $(32.2 \mathrm{MJ} / \mathrm{l})$ is less than that of diesel (35.9 MJ/1) while bioethanol and biodiesel have a calorific value of $21.1 \mathrm{MJ} / \mathrm{l}$ and $32.6 \mathrm{MJ} / \mathrm{l}$, respectively [119].

To cope with the demands, resources and technology available for biodiesel production should be efficiently utilized. Instead of focusing on the drawbacks of each feedstock or biodiesel production process to disprove or discourage its use, these drawbacks should be taken positively to integrate and maximize their use in scenarios where they are most suitable.

\subsection{Use of edible sources for biodiesel}

Compared to non-edible feedstock, edible sources are more readily available and are widely produced for human consumption. Growing of non-edible sources to avoid competition in the food chain may not totally resolve the problem due to competition of land usage. Instead, edible oils may be utilized in the form of used or waste cooking oil together with adipose tissues of poultry and farm animals.

The world production of vegetable oils from 1992 to 2012 (Fig. 4) have increased by as much as 100 million tons in the annual production in a span of 20 years. Based on the databank provided by Food and Agriculture Organization of the United Nations Statistics Division, Over 60\% of the annually produced oils have been utilized as food supply [135]. If the oils utilized in the food chain ends up as used cooking oil, a potential of $\sim 80$ million tons of biodiesel could be produced annually. This amount is enough to cater the current world demand estimated at $\sim 63$ million tons.

A summary of the average annual edible oil produced and the top producing countries of specific oils is shown in Table 17. Palm is the most abundantly produced vegetable oil having a $\sim 30 \%$ share of the annual world production, followed by soybean $(\sim 26 \%)$ and rapeseed $(\sim 15 \%)$. The increase in vegetable oil production is limited to the top five vegetable oils produced (Fig. 4): palm and palm kernel oil (Asia), soybean (Americas), rapeseed and sunflower oils (Europe). These are also the main biodiesel feedstock used by the respective regions.

The increase in the production of these edible oils may be due to the increase in demand as food but may also be due to the use of edible oils as feedstock for biodiesel production. If the collection and utilization of used vegetable oils can be effectively implemented, not only the cost of biodiesel can be reduced but the demand for refined vegetable oil may also be affected. This might result in a decrease in the overall demand of edible oils, which are currently produced to cope with energy demand. Apart from vegetable oils, animal fats can also be tapped for biodiesel production with a potential of $\sim 20$ million tons at the end of 2012 [135]. Even with maximizing the use of available resources, it will only be enough to provide for the current need and will not be able to meet the increasing energy demand, thus utilization of alternative feedstock is inevitable.

\subsection{ISTE process with non-edible feedstock}

An inherent disadvantage of using non-edible feedstock for biodiesel production is its availability and stability in production. Feedstock from various non-edible sources would be preferable to keep up with the demand. Extraction and purification of oil from these non-edible sources is required to meet the requirements of current technology used in industry. This would result in an additional operating cost, which have been estimated and believed by many to be $70-80 \%$ of the overall production cost. From the

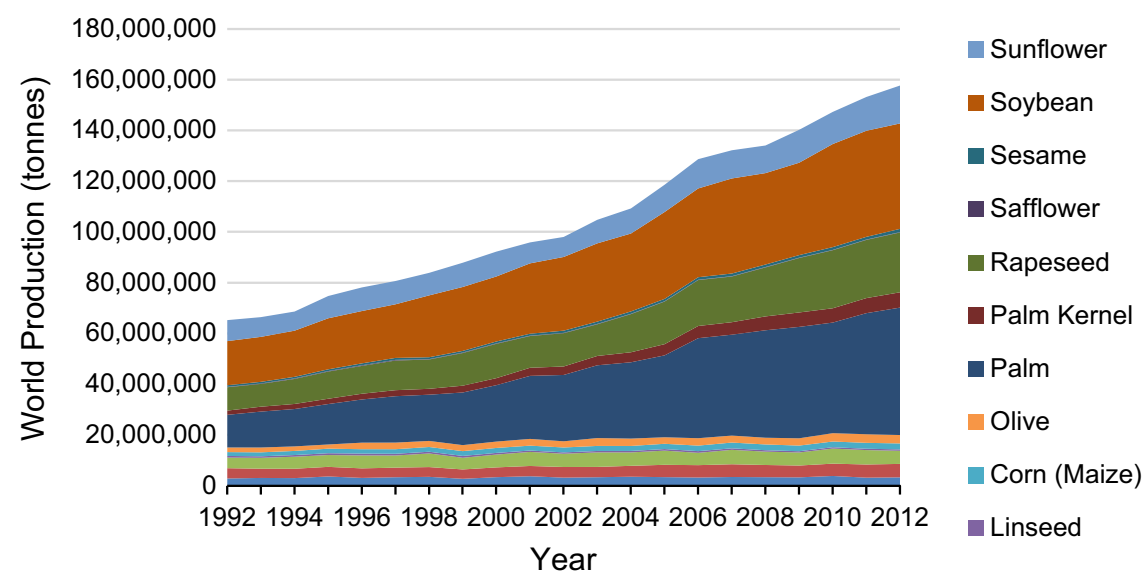

Fig. 4. World annual edible oil production from 1992 to 2012 [135]. 


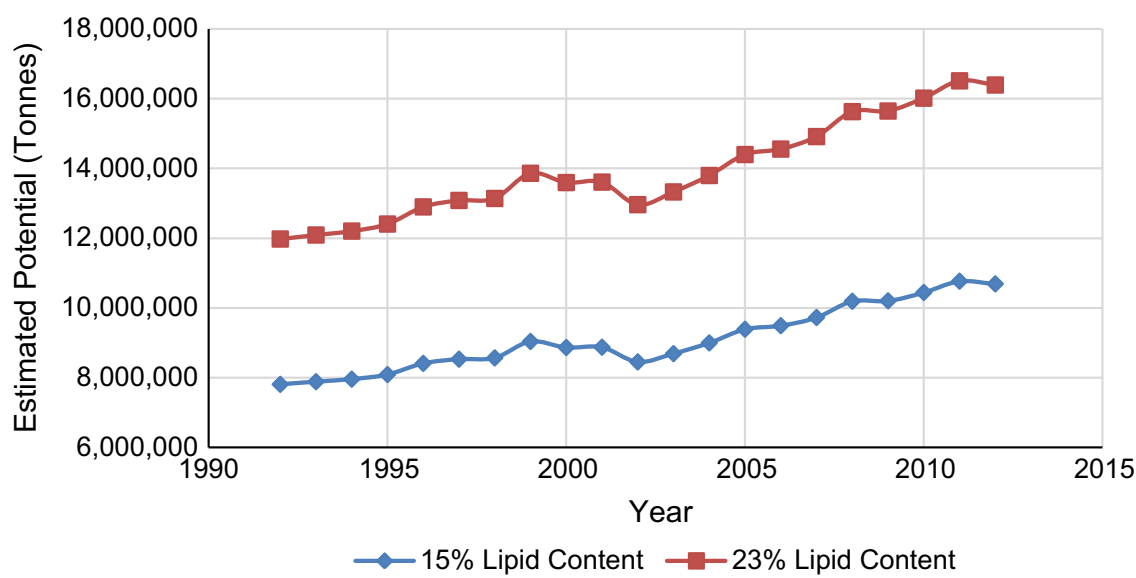

Fig. 5. Potential use of rice bran oil, based on world annual rice paddy production from 1992 to 2012 [135].

discussions in this review ISTE seems to be a potential alternative in addressing this problem through the direct use of feedstock without the need of prior oil extraction. Moreover, researches have shown that process conditions could be optimized to cater to a wide range of feedstock addressing problems regarding moisture and FFA content. In addition the use of ISTE maximizes the utilization of available lipids, not only the storage lipids but also the structural lipids.

Oil containing agricultural and biological residues should be given more attention in biodiesel production as they are widely available at low cost. Among the potential feedstock explored, rice bran constitutes about $11 \%$ of the paddy rice (International Rice Research Institute, IRRI) and contains 15-23\% lipid. As can be seen from Fig. 5, the consumption of rice keeps increasing especially in the past decade. At the end of 2012 a potential of 11-16 million tons of rice bran oil could be utilized for biodiesel production, which could address a quarter of the current world demand for biodiesel.

Although a variety of feedstock have been studied and utilized for ISTE, there are still works to be done to come up with a set of process conditions for the various ISTE technologies, which could cater to a wider range of feedstock. A technology capable of and flexible enough to utilize various feedstock and catering to single or mixed oleaginous biomass would greatly hasten its commercialization. Apart from yield and conversion, improving the available ISTE process overall reaction and productivity should be looked into.

Future studies on ISTE should also look into the reactor design and mixing characteristics in order to provide insights on the scalability of the process. Moreover, innovative reactor configurations and modes (semi batch or continuous) should also be explored to cater feedstock where it would be most favorable.

Furthermore, an integrated bio-refinery approach should be explored together with the advancements in ISTE in order to maximize the utilization of feedstock and to improve process economics. With regards to the process economics a more detailed and realistic model should be developed incorporating its sensitivity to lipid content of feedstock, methanol recycling, cost in downstream processes and waste treatment. Most importantly models developed should incorporate the possibility of using part of the biodiesel produced or solid residues as energy supply in the process so to make it self-sustainable.

\section{Conclusions}

Future biodiesel production requires non-conventional resources such as oleaginous biomass, from which oil and lipids are esterified to produce FAME. ISTE is a promising alternative for the production of biodiesel, which reduces production steps through elimination of biomass pretreatment, lipid extraction and purification steps. It should be noted that only those that involve (trans)esterification reactions within biomass and simultaneously extracts the products and lipid constituents or undergoing reactive extraction are true ISTE.

The technology has been explored with catalytic and noncatalytic approaches each having their own advantages and disadvantages. Future studies on ISTE should clearly indicate the biomass characteristics (particle size and moisture content) and free fatty acid content in the lipids. Apart from feed characteristics, catalyst loading, solvent-to-solid ratio (SSR), solvent to oil ratio (SOR) are important parameters to take into account during ISTE reaction. Under sub and supercritical conditions reactor loading is an important parameter that should be looked into. The use of cosolvents is an effective way to improve solubility of reactants, but would require caution as not to result in a diluted system. Detailed study regarding the mode of heating and mixing should be done, so to have basis for later scale-up of the process. FAME yield should not be the sole indicator, process productivity should also be taken into consideration.

The use of edible sources could be avoided and lipids from such sources could instead be recovered from used/waste oil. Agricultural biomass residues and microbial sources for lipids should be the focus of future researches on ISTE. In order to justify the advantages provided by the process a good techno-economic analysis and process model should be developed incorporating relevant process variables. Moreover a robust and flexible process should be developed to cater feedstock of varying qualities and a self-sustainable, integrated bio-refinery concept should be developed.

\section{References}

[1] Banković-Ilić IB, Stojković IJ, Stamenković OS, Veljkovic VB, Hung Y-T. Waste animal fats as feedstocks for biodiesel production. Renew Sustain Energy Rev 2014:32(0):238-54.

[2] Balat M, Balat H. Progress in biodiesel processing. Appl Energy 2010;87 (6):1815-35.

[3] Kasim FH, Harvey AP, Zakaria R. Biodiesel production by in situ transesterification. Biofuels 2010;1:1-11.

[4] Goembira F, Saka S. Optimization of biodiesel production by supercritical methyl acetate. Bioresour Technol 2013;131(0):47-52.

[5] Goembira F, Matsuura K, Saka S. Biodiesel production from rapeseed oil by various supercritical carboxylate esters. Fuel 2012;97(0):373-8.

[6] Su E-Z, Xu W-Q, Gao K-L, Zheng Y, Wei D-Z. Lipase-catalyzed in situ reactive extraction of oilseeds with short-chained alkyl acetates for fatty acid esters production. J Mol Catal B: Enzym 2007;48(1-2):28-32. 
[7] Fabbri D, Bevoni V, Notari M, Rivetti F. Properties of a potential biofuel obtained from soybean oil by transmethylation with dimethyl carbonate. Fuel 2007;86(5-6):690-7.

[8] Su E-Z, Zhang M-J, Zhang J-G, Gao J-F, Wei D-Z. Lipase-catalyzed irreversible transesterification of vegetable oils for fatty acid methyl esters production with dimethyl carbonate as the acyl acceptor. Biochem Eng J 2007;36 (2):167-73.

[9] Ilham Z, Saka S. Dimethyl carbonate as potential reactant in non-catalytic biodiesel production by supercritical method. Bioresour Technol 2009;100 (5):1793-6.

[10] Su E, You P, Wei D. In situ lipase-catalyzed reactive extraction of oilseeds with short-chained dialkyl carbonates for biodiesel production. Bioresour Technol 2009;100(23):5813-7.

[11] U.S.E.I.A. International Energy Statistics. U.S. Energy Information Administration.

[12] B.P. Statistical Review of World Energy 2013. In: Energy BSRoW, editor. British Petroleum; 2013

[13] Lane J. Biofuels mandates around the world: 2014. Biofuels Digest; 2013, www.biofuelsdigest.com/.../biofuels-mandates-around-the-world-2014/.

[14] Johnston M, Holloway T. A global comparison of national biodiesel production potentials, Environ Sci Technol 2007:41(23):7967-73.

[15] Atabani AE, Silitonga AS, Badruddin IA, Mahlia TMI, Masjuki HH, Mekhilef S A comprehensive review on biodiesel as an alternative energy resource and its characteristics. Renew Sustain Energy Rev 2012;16(4):2070-93.

[16] Harrington K, D’Arcy-Evans C. A comparison of conventional and in situ methods of transesterification of seed oil from a series of sunflower cultivars. J Am Oil Chem Soc 1985;62(6):1009-13.

[17] Dugan Jr. LR, McGinnis GW, Vadehra DV. Low temperature direct methylation of lipids in biological materials. Lipids 1966;1(5):305-8.

[18] Harington KJ, D'Arcy-Evans C. Transesterification in situ of sunflower seed oil. Ind Eng Chem Prod Res Dev 1985;24:314-8.

[19] Lee KT, Lim S, Pang YL, Ong HC, Chong WT. Integration of reactive extraction with supercritical fluids for process intensification of biodiesel production: prospects and recent advances. Prog Energy Combust Sci 2014;45(0):54-78.

[20] Lim S, Hoong SS, Teong LK, Bhatia S. Supercritical fluid reactive extraction of Jatropha curcas L. seeds with methanol: A novel biodiesel production method. Bioresour Technol 2010;101(18):7169-72.

[21] Guldhe A, Singh B, Rawat I, Bux F. Synthesis of biodiesel from Scenedesmus sp. by microwave and ultrasound assisted in situ transesterification using tungstated zirconia as a solid acid catalyst. Chem Eng Res Des 2014.92 (8):1503-11.

[22] Li Y, Lian S, Tong D, Song R, Yang W, Fan Y, et al. One-step production of biodiesel from Nannochloropsis sp. on solid base Mg-Zr catalyst. Appl Energy 2011;88:3313-7.

[23] Dong T, Wang J, Miao C, Zheng Y, Chen S. Two-step in situ biodiesel production from microalgae with high free fatty acid content. Bioresour Techno 2013;136(0):8-15.

[24] Haas M, Scott K. Moisture removal substantially improves the efficiency of in situ biodiesel production from soybeans. J Am Oil Chem Soc 2007;84 (2):197-204

[25] Towler G, Sinnott R. Chapter 2 - Process flowsheet development. In: Towler G, Sinnott R, editors. Chemical engineering design. Second ed.. ButterworthHeinemann; 2013. p. 33-101.

[26] Haas MJ, McAloon AJ, Yee WC, Foglia TA. A process model to estimate biodiesel production costs. Bioresour Technol 2006:97:671-8.

[27] BRDI. National Biofuels Action Plan. Biomass Research and Development Initiative; 2008

[28] Sawangkeaw R, Ngamprasertsith S. A review of lipid-based biomasses as feedstocks for biofuels production. Renew Sustain Energy Rev 2013;25:97108.

[29] Meng X, Yang J, Xu X, Zhang L, Nie Q, Xian M. Biodiesel production from oleaginous microorganisms. Renew Energy 2009;34:1-5.

[30] Kakkad H, Khot M, Zinjarde S, RaviKumar A, Ravi Kumar V, Kulkarni BD. Conversion of dried Aspergillus candidus mycelia grown on waste whey to biodiesel by in situ acid transesterification. Bioresour Technol 2015;197:502 7.

[31] Ma F, Clements LD, Hanna MA. The effects of catalyst, free fatty acids, and water on transesterification of beef tallow. Trans Am Soc Agric Eng 1998;41 (5):1261-4.

[32] Freedman B, Pryde EH, Mounts TL. Variables affecting the yields of fatty esters from transesterified vegetable oils. J Am Oil Chem Soc 1984;61 (10):1638-43.

[33] Canakci M. The potential of restaurant waste lipids as biodiesel feedstocks. Bioresour Technol 2007:98(1):183-90.

[34] Atadashi IM, Aroua MK, Abdul Aziz AR, Sulaiman NMN. The effects of water on biodiesel production and refining technologies: a review. Renew Sustain Energy Rev 2012:16(5):3456-70.

[35] Kusdiana D, Saka S. Effects of water on biodiesel fuel production by supercritical methanol treatment. Bioresour Technol 2004;91(3):289-95.

[36] Minami E, Saka S. Kinetics of hydrolysis and methyl esterification for biodiesel production in two-step supercritical methanol process. Fuel 2006;85 $(17-18): 2479-83$.

[37] Ju Y-H, Huynh LH, Tsigie YA, Ho Q-P. Synthesis of biodiesel in subcritica water and methanol. Fuel 2013;105:266-71.
[38] Go AW, Tran Nguyen PL, Huynh LH, Liu Y-T, Sutanto S, Ju Y-H. Catalyst free esterification of fatty acids with methanol under subcritical condition. Energy 2014;70(0):393-400.

[39] Chen L, Liu T, Zhang W, Chen X, Wang J. Biodiesel production from algae oil high in free fatty acids by two-step catalytic conversion. Bioresour Technol 2012;111(0):208-14.

[40] Huang G, Chen F, Wei D, Zhang X, Chen G. Biodiesel production by microalgal biotechnology. Appl Energy 2010;87:38-46.

[41] Thevenieau F, Nicaud J-M. Microorganisms as sources of oils. Oilseeds Fats Crops Lipids 2013;20(6):D603.

[42] Go AW, Sutanto S, Liu Y-T, Nguyen PLT, Ismadji S, Ju Y-H. In situ transesterification of Jatropha curcas L. seeds in subcritical solvent system. J Taiwan Inst Chem E 2014;45(0):1516-22.

[43] Zullaikah S, Lai C-C, Vali SR, Ju Y-H. A two-step acid-catalyzed process for the production of biodiesel from rice bran oil. Bioresour Technol 2005;96 (17):1889-96.

[44] Tsigie YA, Huynh LH, Ahmed IN, Ju Y-H. Maximizing biodiesel production from Yarrowia lipolytica Po1g biomass using subcritical water pretreatment. Bioresour Technol 2012;111(0):201-7.

[45] Tran Nguyen PL, Go AW, Huynh LH, Ju Y-H. A study on the mechanism of subcritical water treatment to maximize extractable cellular lipids. Biomass Bioenergy 2013;59(0):532-9.

[46] Park J-Y, Park MS, Lee Y-C, Yang J-W. Advances in direct transesterification of algal oils from wet biomass. Bioresour Technol 2015;184:267-75.

[47] Isayama Y, Saka S. Biodiesel production by supercritical process with crude bio-methanol prepared by wood gasification. Bioresour Technol 2008;99 (11):4775-9.

[48] Li Q Xu J, Du W, Li Y, Liu D. Ethanol as the acyl acceptor for biodiesel production. Renew Sustain Energy Rev 2013;25(0):742-8.

[49] Ang GT, Tan KT, Lee KT. Recent development and economic analysis of glycerol-free processes via supercritical fluid transesterification for biodiesel production. Renew Sustain Energy Rev 2014;31(0):61-70.

[50] Saka S, Isayama Y. A new process for catalyst-free production of biodiesel using supercritical methyl acetate. Fuel 2009;88(7):1307-13.

[51] Saka S, Isayama Y, Ilham Z, Jiayu X. New process for catalyst-free biodiesel production using subcritical acetic acid and supercritical methanol. Fuel 2010:89(7):1442-6.

[52] Go A, Liu Y-T, Ju Y-H. Applicability of subcritical water treatment on oil seeds to enhance extractable lipid. Bioenergy Res 2013;7(2):711-9.

[53] Siler-Marinkovic S, Tomasevic A. Transesterification of sunflower oil in situ. Fuel 1998;77(12):1389-91.

[54] Ozgul-Yucel S, Turkay S. Varriables affecting the yields of methyl esters derived from in situ esterification of rice bran oil. J Am Oil Chem Soc 2002;79:611-4.

[55] Ozgul-Yucel S, Turkay S. FA monoalkylesters from rice bran oil by in situ esterification. J Am Oil Chem Soc 2003;80(1):81-4.

[56] Yustianingshi L, Zullaikah S, Ju Y-H. Ultrasound-assisted in-situ production of biodiesel from rice bran. J Energy Inst 2009;82:133-7.

[57] Atadashi IM, Aroua MK, Aziz ARA, Sulaiman NMN. The effects of catalysts in biodiesel production: a review. J Ind Eng Chem 2013;19:14-26.

[58] Haas M, Scott K, Marmer W, Foglia T. In situ alkaline transesterification: an effective method for the production of fatty acid esters from vegetable oils. J Am Oil Chem Soc. 2004;81(1):83-9.

[59] Haas M, Scott K, Foglia T, Marmer W. The general applicability of in situ transesterification for the production of fatty acid esters from a variety of feedstocks. J Am Oil Chem Soc. 2007;84(10):963-70.

[60] Velasquez-Orta SB, Lee JGM, Harvey A. Alkaline in situ transesterification of Chlorella vulgaris. Fuel 2012:94:544-50.

[61] Tran D-T, Le B-H, Lee D-J, Chen C-L, Wang HY, Chang J-S. Microalgae harvesting and subsequent biodiesel conversion. Bioresour Technol 2013:140:179-86.

[62] Wu H, Liu Y, Zhang J, Li G. In situ reactive extraction of cottonseeds with methyl acetate for biodiesel production using magnetic solid acid catalysts. Bioresour Technol 2014:174:182-9.

[63] Shui P-J, Gunawan S, Hsieh W-H, Kasim NS, Ju Y-H. Biodiesel production frim rice bran by two-step in-situ process. Bioresour Technol 2010;101:984-9.

[64] Hincapie G, Mondragon F, Lopez D. Conventional and in situ transesterifictaion of castor seed oil for biodiesel production. Fuel 2011:90:1618-23.

[65] Jaliliannosrati H, Amin NAS, Talebian-Kiakalaieh A, Noshadi I. Microwave assisted biodiesel production from Jatropha curcas $L$. seed by two-step in situ process: Optimization using response surface methodology. Bioresour Technol 2013;136:565-73.

[66] Lei H, Ding XF, Zhang HX, Chen X, Li YL, Zhang H, et al. In situ production of fatty acid methyl ester from low quality rice bran: an economical route for biodiesel production. Fuel 2010;89(7):1475-9.

[67] Lei H, Ding XF, Zhao JZ, Zhang HX, Li YL, Ma YJ, et al. In situ production of fatty acid ethyl ester from low quality rice bran. Fuel 2011;90(2):592-7.

[68] Dong T, Wang J, Miao C, Zheng Y, Chen S. Two-step in situ biodiesel production from microalgae with high free fatty acid content. Bioresour Technol 2013;136:8-15.

[69] Gu H, Jiang Y, Zhou L, Gao J. Reactive extraction and in situ self-catalyzed methanolysis of germinated oilseed for biodiesel production. Energy Environ Sci 2011;4(4):1337-44.

[70] Jiang Y, Gu H, Zhou L, Cui C, Gao J. Novel in situ batch reactor with a facile catalyst separation device for biodiesel production. Ind Eng Chem Res 2012;51(46):14935-40. 
[71] Jiang Y, Li D, Li Y, Gao J, Zhou L, He Y. In situ self-catalyzed reactive extraction of germinated oilseed with short-chained dialkyl carbonates for biodiesel production. Bioresour Technol 2013;150(0):50-4.

[72] Tran D-T, Yeh K-L, Chen C-L, Chang J-S. Enzymatic transesterification of microalgal oil from Chlorella vulgaris ESP-31 for biodiesel synthesis using immobilized Burkholderia lipase. Bioresour Technol. 2012;108(0):119-27.

[73] Bunyakiat K, Makmee S, Sawangkeaw R, Ngamprasertsith S. Continuous production of biodiesel via transesterification from vegetable oils in supercritical methanol. Energy Fuels 2006;20(2):812-7.

[74] Lim S, Lee K-T. Influences of different co-solvents in simultaneous supercritical extraction and transesterification of Jatropha curcas $L$. seeds for the production of biodiesel. Chem Eng J 2013;221(0):436-45.

[75] Go AW, Sutanto S, NguyenThi BT, Cabatingan LK, Ismadji S, Ju Y-H. Transesterification of soybean oil with methanol and acetic acid at lower reaction severity under subcritical conditions. Energy Convers Manag 2014;88 (0):1159-66.

[76] Saka S, Kusdiana D. Biodiesel fuel from rapeseed oil as prepared in supercritical methanol. Fuel 2001;80(2):225-31.

[77] Levine RB, Pinnarat T, Savage PE. Biodiesel production from wet algal biomass through in situ lipid hydrolysis and supercritical transesterification. Energy Fuels 2010;24:5235-43.

[78] Glisic SB, Orlović AM. Review of biodiesel synthesis from waste oil under elevated pressure and temperature: phase equilibrium, reaction kinetics, process design and techno-economic study. Renew Sustain Energy Rev 2014;31(0):708-25.

[79] Lim S, Lee KT. Optimization of supercritical methanol reactive extraction by response surface methodology and product characterization from Jatropha curcas L. seeds. Bioresour Technol 2013;142(0):121-30.

[80] Wyatt V, Haas M. Production of fatty acid methyl esters via the in situ transesterification of soybean oil in carbon dioxide-expanded methanol. J Am Oil Chem Soc 2009;86(10):1009-16.

[81] Lim S, Lee KT. Investigation of impurity tolerance and thermal stability for biodiesel production from Jatropha curcas L. seeds using supercritical reactive extraction. Energy 2014;68(0):71-9.

[82] Go AW, Sutanto S, Tran-Nguyen PL, Ismadji S, Gunawan S, Ju Y-H. Biodiesel production under subcritical solvent condition using subcritical water treated whole Jatropha curcas seed kernels and possible use of hydrolysates to grow Yarrowia lipolytica. Fuel 2014;120(0):46-52.

[83] Shin H-Y, Ryu J-H, Park S-Y, Bae S-Y. Thermal stability of fatty acids in subcritical water. J Analy Appl Pyrolysis 2012:98(0):250-3.

[84] Imahara H, Minami E, Hari S, Saka S. Thermal stability of biodiesel in supercritical methanol. Fuel 2008;87(1):1-6.

[85] Levine RB, Bollas A, Savage PE. Process improvements for the supercritical in situ transesterification of carbonized algal biomass. Bioresour Technol 2013;136(0):556-64.

[86] Levine RB, Bollas AA, Durham MD, Savage PE. Triflate-catalyzed (trans) esterification of lipids within carbonized algal biomass. Bioresour Technol 2012;111:222-9.

[87] Levine RB, Sierra COS, Hockstad R, Obeid W, Hatcher PG, Savage PE. The use of hydrothermal carbonization to recycle nutrients in algal biofuel production. Environ Prog Sustain Energy 2013;32(4):962-75.

[88] Kildiran G, Yücel S, Türkay S. In-situ alcoholysis of soybean oil. J Am Oil Chem Soc 1996;73(2):225-8.

[89] Qian JF, Wang F, Liu S, Yun Z. In situ alkaline transesterification of cottonseed oil fro prodcution of biodiesel and nontoxic cottonseed meal. Bioresour Technol 2008;99:9009-12.

[90] Zakaria R, Harvey AP. Direct production of biodiesel from rapeseed by reactive extraction/in situ transesterification. Fuel Process Technol 2012;102 (0):53-60.

[91] Kasim FH. In situ transesterification of Jatropha curcas for biodiesel production. United Kingdom: Newcastle University; 2012.

[92] Sutanto S, Go A, Ismadji S, Ju Y-H. Taguchi method and Grey relational analysis to improve in situ production of FAME from sunflower and Jatropha curcas kernels with subcritical solvent mixture. J Am Oil Chem Soc 2015;92 (10):1513-23.

[93] Chapagain BP, Yehoshua Y, Wiesman Z. Desert date (Balanites aegyptiaca) as an arid lands sustainable bioresource for biodiesel. Bioresour Technol 2009:100(3):1221-6.

[94] Tran D-T, Yeh K-L, Chen C-L, Chang J-S. Enzymatic transesterification of microalgal oil from Chlorella vulgaris ESP-31 for biodiesel synthesis using immobilized Burkholderia lipase. Bioresour Technol 2012:108:119-27.

[95] Haas M, Wagner K. Substrate pretreatment can reduce the alcohol requirement during biodiesel production via in situ transesterification. J Am Oil Chem Soc 2011;88(8):1203-9.

[96] Georgogianni KG, Kontominas MG, Pomonis PJ, Avlontis D, Gergis V. Conventinal and insitu transesterification of sunflower seed oil for the production of biodiesel. Fuel Proc Technol 2008;89:503-9.

[97] Georgogianni KG, Kontominas MG, Pomonis PJ, Avlontis D, Gergis V. Alkaline conventiona and in situ transesterifictaion of cottonseed oil for the production of biodiesel. Energy Fuels 2008;22:2110-5.

[98] Go AW, Sutanto S, Liu Y-T, Nguyen PLT, Ismadji S, Ju Y-H. In situ transesterification of Jatropha curcas L. seeds in subcritical solvent system. J Taiwan Inst Chem E 2014;45(4):1516-22.

[99] Go AW, Sutanto S, Zullaikah S, Ismadji S, Ju Y-H. A new approach in maximizing and direct utilization of whole Jatropha curcas L. kernels in biodiesel production - technological improvement. Renew Energy 2016;85:759-65.
[100] Patil PD, Gude VG, Mannarswamy A, Cooke P, Nirmalakhandan N, Lammers $\mathrm{P}$, et al. Comparison of direct transesterification of algal biomass under supercritical methanol and microwave irradiation conditions. Fuel 2012;97:822-31.

[101] Patil PD, Reddy H, Muppaneni T, Ponnusamy S, Cooke P, Schuab T, et al. Microwave-mediated non-catalytic transesterification of algal biomass under supercritical ethanol conditions. J Supercrit Fluids 2013;79(0):67-72.

[102] Patil PD, Gude VG, Mannarswamy A, Cooke P, Munson-McGee S, Nirmalakhandan $\mathrm{N}$, et al. Optimization of microwave-assisted transesterification of dry algal biomass using response surface methodology. Bioresour Techno 2011;102(2):1399-405.

[103] Patil P, Reddy H, Muppaneni T, Ponnusamy S, Sun Y, Dailey P, et al. Optimization of microwave-enhanced methanolysis of algal biomass to biodiese under temperature controlled conditions. Bioresour Technol 2013;137 (0):278-85.

[104] Patil PD, Reddy H, Muppaneni T, Schaub T, Holguin FO, Cooke P, et al. In situ ethyl ester production from wet algal biomass under microwave-mediated supercritical ethanol conditions. Bioresour Technol 2013;139(0):308-15.

[105] Chen K-S, Lin Y-C, Hsu K-H, Wang H-K. Improving biodiesel yields from waste cooking oil by using sodium methoxide and a microwave heating system. Energy 2012;38(1):151-6.

[106] Huynh LH, Nguyen PLT, Ho QP, Ju Y-H. Catalyst-free fatty acid methyl ester production from wet activated sludge under subcritical water and methanol condition. Bioresour Technol 2012;123:112-6.

[107] Tsigie YA, Huynh LH, Ismadji S, Engida AM, Ju Y-H. In situ biodiesel production from wet Chlorella vulgaris under subcritical condition. Chem Eng J 2012;213:104-8.

[108] Tsigie YA, Huynh LH, Nguyen PLT, Ju Y-H. Catalyst-free biodiesel preparation from wet Yarrowia lipolytica Po1g biomass under subcritical condition. Fuel Process Technol 2013;115:50-6.

[109] Royon D, Locatelli S, Gonzo EE. Ketalization of glycerol to solketal in supercritical acetone. J Supercrit Fluids 2011;58(1):88-92.

[110] Thanh LT, Okitsu K, Sadanaga Y, Takenaka N, Maeda Y, Bandow H. A new cosolvent method for the green production of biodiesel fuel - optimization and practical application. Fuel 2013;103(0):742-8.

[111] Hailegiorgis SM, Shuhami Mahadzir, Subbarao D. Enhanced in situ ethanolysis of Jatropha curcas L. in the prescence of cetylammonium bromide as a phase transfer catalyst. Renew Energy 2011;36:2502-7.

[112] Hailegiorgis SM, Shuhami Mahadzir, Subbarao D. Parametric study and optimization of in situ tranesterification of Jatropha curcas L. assisted by benzyltrimethylammonium hydroxide as a phase transfer catalyst via response surface methodology. Biomass Bioenergy 2013;49:63-73.

[113] Lim S, Lee KT. Process intensification for biodiesel production from Jatropha curcas L. seeds: supercritical reactive extraction process parameters study. Appl Energy 2013;103(0):712-20.

[114] Kasim FH, Harvey AP. Influence of various parameters on reactive extraction of Jatropha curcas L. for biodiesel production. Chem Eng J 2011;171(3):13738.

[115] Ehimen EA, Sun Z, Carrington GC. Use of ultrasound and co-solvents to improve the in-situ transesterification of microalgae biomass. Procedia Environ Sci 2012:15:47-55.

[116] Calixto F, Fernandes J, Couto R, Hernandez EJ, Najdanovic-Visak V, Simoes PC Synthesis of fatty acid methyl estersvia direct transesterification with methanol/carbon dioxide mixtures from spent coffee grounds feedstock. Green Chem 2011;13(5):1196-202.

[117] Lim S, Lee KT. Effects of solid pre-treatment towards optimizing supercritical methanol extraction and transesterification of Jatropha curcas L. seeds for the production of biodiesel. Sep Purif Technol 2011;81(3):363-70.

[118] Lim S, Teong LK. Recent trends, opportunities and challenges of biodiesel in Malaysia: an overview. Renew Sustain Energy Rev 2010;14(3):938-54.

[119] Energy USDo. Clean cities alternative fuel price report. U.S: Department of Energy; 2014.

[120] Commission E. Europe Commision-Energy Policy. Europe Commission; 2014

[121] Samuel OD, Dairo OU. A critical review on in-situ transesterification process for biodiesel production. Pac J Sci Technol. 2012;13:72-9.

[122] Core J. New method simplifies biodiesel production. Agric Res 2005:13.

[123] Revellame E, Hernandez R, French W, Holmes W, Alley E. Biodiesel from activated sludge through in-situ transesterification. J of Chem Technol and Biotechnol 2010;85:614-20.

[124] Mondala A, Liang K, Toghiani H, Hernandez R, French T. Biodiesel production by in situ transesterification of municipal primary and secondary sludges Bioresour Technol 2009;100:1203-10.

[125] Revellame E, Hernandez R, French W, Holmes W, Alley E, II RC. Production of biodiesel from wet activated sludge. J Chem Technol Biotechnol 2011;86:618.

[126] Dufreche S, Hernandez R, French T, Sparks D, Zappi M, Alley E. Extraction of lipids from municipal wastewater plant microorganisms for production of biodiesel. J Am Oil Chem Soc 2007:84:181-7.

[127] Koutinas AA, Chatzifragkou A, Kopsahelis N, Papanikolaou S, Kookos IK Design and techno-economic evaluation of microbial oil production as a renewable resource for biodiesel and oleochemical production. Fuel 2014;116 (0):566-77.

[128] Im H, Kim B, Lee JW. Concurrent production of biodiesel and chemicals through wet in situ transesterification of microalgae. Bioresour Technol 2015;193:386-92. 
[129] Abo El-Enin SA, Attia NK, El-Ibiari NN, El-Diwani GI, El-Khatib KM. In-situ transesterification of rapeseed and cost indicators for biodiesel production. Renew Sustain Energy Rev 2013;18(0):471-7.

[130] Qian JF, Yun Z. Cogeneration of biodiesel and nontoxic cottonseed meal from cottonseed through in situ alkaline transesterification. Energy Fuels 2009;23 (1):507-12.

[131] Qian J, Yang Q, Sun F, He M, Chen Q, Yun Z, et al. Cogeneration of biodiesel and nontoxic rapeseed meal from rapeseed through in-situ alkaline transesterification. Bioresour Technol 2013;128(0):8-13.

[132] Fabian C, Ju Y-H. A review on rice bran protein: its properties and extraction methods. Crit Rev Food Sci Nutr 2011:51(9):816-27.

[133] Tsigie YA, Wang C-Y, Kasim NS, Diem Q-D, Huynh L-H, Ho Q-P, et al. Oil production from Yarrowia lipolytica Po1g using rice bran hydrolysate. J Biomed Biotechnol 2012;2012:10.

[134] Tsigie YA, Wu C-H, Huynh LH, Ismadji S, Ju Y-H. Bioethanol production from Yarrowia lipolytica Po1g biomass. Bioresour Technol. 2013;145(0):210-6.

[135] FAOSTAT. Production/Crops Processed. Food and Agricultural Organization of the United Nations Statistics Division; 2014.

[136] U.S.E.I.A. Monthly energy review. U.S: Energy Information Administration; 2014. p. 142.

[137] Fernandez CM, Ramos MJ, Perez A, Rodriguez JF. Production of biodiesel from winery waste: extraction, refining and transesterification of grape seed oil. Bioresour Technol 2010;101(18):7030-5.

[138] Ginting MSA, Azizan MT, Yusup S. Alkaline in situ ethanolysis of Jatropha curcas. Fuel 2012;93(1):82-5.

[139] Gunawan S, Maulana S, Anwar K, Widjaja T. Rice bran, a potential source of biodiesel production in Indonesia. Ind Crops Prod 2011;33(3):624-8.

[140] Haagenson D, Brudvik R, Lin H, Wiesenborn D. Implementing an in situ alkaline transesterification method for canola biodiesel quality screening. J Am Oil Chem Soc 2010;87(11):1351-8.

[141] Jairurob P, Phalakornkule C, Na-udom A, Petiraksakul A. Reactive extraction of after-stripping sterillized palm fruit to biodiesel. Fuel 2013;107:282-9.

[142] Kartika IA, Yani M, Ariono D, Evon P, Rigal L. Biodiesel production from jatropha seeds: Solvent extraction and in situ transesterification in a single step. Fuel 2013;106(106):111-7.

[143] Kasim NS, Tsai TH, Gunawan S, Ju YH. Biodiesel production from rice bran oil and supercritical methanol. Bioresour Technol 2009;100(8):2399-403.

[144] Kaul S, Porwal J, Garg MO. Parametric study of jatropha seedsfor biodiesel production by reactive extraction. J Am Oil Chem Soc 2010;87:903-8.

[145] Khang DS, Razon LF, Madrazo CF, Tan RR. In situ transesterification of coconut oil using mixtures of methanol and tetra hydrofuran. Chem Eng Res Des 2014.

[146] Kurinawan A, Effendi C, Ong LK, Ju Y-H, Lin CX, Ismadji S. Novel, integrated biorefinery approach of Ceiba pentadra (Kapok) seed and its secondary waste. Sustain Chem Eng 2013;1:473-80.

[147] Pradhan S, Madankar CS, Mohanty P, Naik SN. Optimization of reactive extraction of castor seed to produce biodiesel using response surface methodology. Fuel 2012;97:848-55.

[148] Shuit SH, Lee KT, Kamaruddin AH, Yusup S. Reactive extraction and in situ etsterification of Jatropha curcas L. seeds for the production of biodiesel. Fuel 2010;89:527-30.
[149] Shuit SH, Lee KT, Kamaruddin AH, Yusup S. Reactive extraction of Jatropha curcas L. seed for production of biodiesel: process optimization study. Environ Sci Technol 2010;44(11):4361-7.

[150] Sulaiman S, Aziz ARA, Aroua MK. Reactive extraction of solid coconut waste to produce biodiesel. J Taiwan Inst Chem E 2013;44(2):233-8.

[151] Zeng JL, Wang XD, Zhao B, Sun JC, Wang YC. Rapid in situ transesterification of sunflower oil. Ind Eng Chem Res 2009;48(2):850-6.

[152] D'Oca MGM, Viegas CV, Lemoes JS, Miyasaki EK, Moron-Villarreyes JA, Primel EG, et al. Production of FAMEs from several microalgal lipidic extracts and direct transesterification of Chlorella pyrenoidosa. Biomass Bioenergy 2011;35:1533-8

[153] Li P, Miao X, Li R, Zhong J. In situ biodiesel production from fast-growing and high oil content Chlorella pyrenoidosa in rice straw hydrolysate. J Biomed Biotechnol 2011;2011:8.

[154] Cao H, Zhang Z, Wu X, Miao X. Direct biodiesel production from wet microalgae biomass of Chlorella pyrenoidosa through in-situ transesterification. Biomed Res Int 2013;2013.

[155] Ehimen EA, Sun ZF, Carrington CG. Variables affecting the in situ transesterification of microalgae lipids. Fuel 2010;89:677-84.

[156] Im HJ, Lee HS, Park MS, Yang J-W, Lee JW. Concurrent extraction and reaction for the production of biodiesel from wet microalgae. Bioresour Technol 2014;152:534-7.

[157] Thliveros P, Kiran EU, Webb C. Microbial biodiesel production by direct methanolysis of oleaginous biomass. Bioresour Technol 2014;157:181-7.

[158] Liu B, Zhao Z. Biodiesel production by direct methanolysis of oleaginous microbial biomass. J Chem Technol Biotechnol 2007;82:775-80.

[159] Jo YJ, Lee OK, Lee EY. Dimethyl carbonate-mediated lipid extraction and lipase-catalyzed in situ transesterification for simultaneous preparation of fatty acid methyl esters and glycerol carbonate from Chlorella sp. KR-1 biomass. Bioresour Technol 2014;158(0):105-10.

[160] Ani AY, Ishak MAN, Ismail K. Production of biodiesel via in-situ supercritical methanol transesterification. In: Stotcheva M, editor. Biodiesel-feedstock and processing technologies. Croatia: Intech; 2011. p. 229-46.

[161] Zullaikah S, Simatupang EZ, Siregar RG, Rakhadima YT, Rachimoellah M. In situ production of biodiesel from rice bran oil under subcritical water and methanol. J Tek Kimia Indones 2014;11(6):300-6.

[162] Mandotra SK, Kumar P, Suseela MR, Ramteke PW. Fresh water green microalga Scenedesmus abundans: a potential feedstock for high quality biodiesel production. Bioresour Technol 2014;156:42-7.

[163] Chuck CJ, Lou-Hing D, Dean R, Sergeant LA, Scott RJ, Jenkins RW. Simultaneous microwave extraction and synthesis of fatty acid methyl ester from the oleaginous yeast Rhodotorula glutinis. Energy 2014:1-9.

[164] Sitthithanaboon W, Reddy HK, Muppaneni T, Ponnusamy S, Punsuvon V, Holguim F, et al. Single-step conversion of wet Nannochloropsis gaditana to biodiesel under subcritical methanol conditions. Fuel 2015;147:253-9.

[165] Patil PD, Gude VG, Mannarswamy A, Deng S, Cooke P, Munson-McGee S, et al. Optimization of direct conversion of wet algae to biodiesel under supercritical methanol conditions. Bioresour Technol 2011;102(1):118-22.

[166] Reddy HK, Muppaneni T, Patil PD, Ponnusamy S, Cooke P, Schaub T, et al. Direct conversion of wet algae to crude biodiesel under supercritical under supercritical ethanol conditions. Fuel 2014;115:720-6. 